\title{
Gambling and Financial Stress
}

\author{
Isaac Koomson $^{1,2}$ (D) Sefa Awaworyi Churchill ${ }^{3}$. Musharavati Ephraim Munyanyi ${ }^{3}$
}

Accepted: 3 February 2022 / Published online: 7 March 2022

(c) The Author(s) 2022

\begin{abstract}
In recent years, gambling harm has been considered a significant public health concern due to its increasing socioeconomic costs. Although the adverse effects of gambling have attracted research interest, evidence of its effect on financial stress remains largely anecdotal. This study empirically examines the link between individual problem gambling severity and financial stress using panel data from the household, income and labour dynamics in Australia survey. After addressing endogeneity, we find that problem gambling severity is positively associated with self-reported financial stress. Thus, problem gambling severity tends to increase financial stress. This finding is robust to alternative measures of financial stress and gambling behaviour-whether gambling is measured using the problem gambling severity index, gambling risk statuses, number of gambling activities, or gambling expenditure. The positive effect of gambling on financial stress is largely driven by gambling activities involving scratch cards and poker machines. Although males exhibit higher levels of problem gambling severity, females are more financially stressed than males. Our findings also suggest that gambling widens the gender gap in financial stress. Further analysis reveals that financial resilience mediates the gambling-financial stress relationship. This implies that promoting policies that enhance financial resilience can help to insulate individuals against the effects of gambling on financial stress.
\end{abstract}

Keywords Gambling · Financial stress · Financial resilience · PGSI · Australia

Isaac Koomson

ikoomso2@une.edu.au; koomsonisaac@gmail.com

Sefa Awaworyi Churchill

sefa.churchill@rmit.edu.au

Musharavati Ephraim Munyanyi

ephraim.munyanyi@rmit.edu.au

1 UNE Business School, Faculty of Science, Agriculture, Business and Law, University of New England, Armidale, NSW, Australia

2 Network for Socioeconomic Research and Advancement (NESRA), Accra, Ghana

3 School of Economics, Finance and Marketing, RMIT University, Melbourne, Australia 


\section{Introduction}

\subsection{Background}

Gambling is a well-known and generally accepted form of leisure (Awaworyi Churchill \& Farrell, 2020a; Calado \& Griffiths, 2016). However, considering global statistics on the proliferation of gambling and its high estimated costs to society, gambling is increasingly becoming an issue in many countries and is now considered a significant public health concern (Calado \& Griffiths, 2016). Although generally not a problem for many individuals, gambling is addictive and problematic for some people (Kalischuk et al., 2006), and has been found to negatively influence health and wellbeing, employment, relationships and social capital, among other outcomes (see, Awaworyi Churchill \& Farrell, 2018, 2020b; Blanco et al., 2012; Griswold \& Nichols, 2006; Paterson et al., 2020; Quigley et al., 2015). Among the various types of gambling, electronic gaming machines which are designed with continuous-play formats have the strongest association with problem gambling (Allami et al., 2021). The technology, number of bets available, winnings, and pay-out rates associated with electronic gaming machines have made them the most addictive form of gambling, with some authors considering them analogous to 'crack-cocaine' (Dowling et al., 2005). The prevalence of problem gambling is estimated to be between 0.1 and $3.4 \%$ globally (Calado \& Griffiths, 2016). The implications of gambling also extend beyond the gambler, with harmful consequences for families and friends that include family violence, insomnia, child health problems, physical illness, and stress (Darbyshire et al., 2001; Dowling et al., 2018; Kalischuk, 2010; Kalischuk et al., 2006; Kourgiantakis et al., 2013; Suomi et al., 2013). Although a large body of research examines the implications and adverse effects of gambling, surprisingly, very little evidence exists on the impact of gambling on financial stress. Financial stress is the difficulty faced by an individual or a household in meeting basic financial commitments due to a shortage of money (Bray, 2001).

A review of the literature shows that, depending on the context, gambling can either lead to or ease financial stress. On the one hand, there is existing theoretical and empirical evidence to support the expectation that problem gambling could lead to financial distress and decreased financial inclusion (e.g., Muggleton et al., 2021; Oksanen et al., 2018). Based on the theoretical expositions of the pathways model of problem and pathological gambling (e.g., Blaszczynski \& Nower, 2002; Tabri et al., 2022), it is implied that problem gambling, which is developed through loss chasing behaviour, can lead to financial losses, with negative implications for financial stress. Generally, intense gambling can lead to loss of savings and accrued debt (Mathews \& Volberg, 2013). Gambling is also associated with other lifestyle adjustments that can be financial stressors. This can include home downsizing, longer work hours to generate more income, the adoption of various cost-cutting measures, and even job loss because of psychological issues linked with gambling (Mathews \& Volberg, 2013; McComb et al., 2009). Financial motives for gambling can lead to illusions of control over gambling outcomes and the misconception that the probability of winnings occurring is high, leading to problem gambling behaviours (Xu \& Harvey, 2014). Accordingly, financial stress might motivate some people to gamble if they irrationally dwell on the illusion of control and perceive gambling as an opportunity to win big, which is typically unlikely given the relatively small odds of big wins (Stöckl et al., 2015; Xu \& Harvey, 2014).

On the other hand, winnings from gambling can also help to reduce financial stress. According to a study by Furaker and Hedenus (2009), some gamblers used their winnings 
to buy new houses/apartments, for home improvements, new cars, loan repayments, investments in stocks, and savings. Considering the gambling winning-employment nexus, Larson (2011) has shown that most employees who gamble continue to work in their existing jobs after winning and save or invest their windfall gains. Investment of gambling winnings into durables and financial asset accumulations can increase economic independence and provide security against economic shocks (Furaker \& Hedenus, 2009; Koomson et al., 2021).

Gender differences exist in problem gambling and financial stress. Evidence indicates that financial stress and its multiple forms are more prevalent among females (Bray, 2001). On the contrary, problem gambling severity is higher among males (Awaworyi Churchill et al., 2019; Calado \& Griffiths, 2016). The information above provide traces of anecdotal evidence to suggest that gambling influences financial stress (Central Coast Gambling Help, 2017; Dickson-Swift et al., 2005; Muggleton, 2021; Swanton \& Gainsbury, 2020). However, no study has empirically examined if this is the case in a large, representative sample.

\subsection{Overview of the Current Study and Contributions to the Literature}

We contribute to the literature by examining how gambling relates to self-reported financial stress using a large, representative sample of Australians. Importantly, not only do we provide evidence of the impact of gambling on financial stress, but we also examine the potential gender gap in financial stress and if financial resilience is a channel through which gambling transmits to financial stress. Specifically, we ask the questions: (a) is there a gender gap in financial stress among gamblers?; (b) does gambling narrow or widen the potential gender gap in financial stress?; (c) does financial resilience provide the needed insulation to dampen the effect of gambling on financial stress? Answering these research questions fills an important gap in the literature given the general lack of empirical studies examining the impact of gambling on financial stress, and more importantly, the mechanisms through which gambling transmits to financial stress. Since financial resilience relates to the ability to come up with an emergency fund in times of financial distress, which could emanate from gambling, (see, e.g., Lusardi et al., 2020), it is expected that financial resilience can be a pathway through which financial stress associated with gambling can be alleviated. Understanding the potential role of financial resilience in serving as an insulator against financial stress that may result from gambling is important for policy and the design of interventions aimed at reducing financial stress.

We use data from the Household, Income and Labour Dynamics in Australia (HILDA) Survey, which is a nationally representative survey of Australians. To measure gambling, we use the Problem Gambling Severity Index (PGSI). We use four measures of financial stress capturing different indicators: financial difficulty, cashflow, hardship, and any stress. Given that gambling is likely to be endogenous, we instrument for gambling using the number of gamblers in respondents' neighbourhoods but outside their households.

The Australian context is essential and makes for an important case study for at least two reasons. First, trends and expenditures on gambling make Australia an important context. Australia has the world's highest gambling expenditure per person with very high social costs of gambling (Awaworyi Churchill \& Farrell, 2019). It is estimated that about 193,000 (1.1\%) of Australian adults are problem gamblers (Armstrong \& Carroll, 2017). Australians gamble over $\$ 200$ billion per year and in the 2018/19 financial year, total gambling loss was \$25.01 billion, which represents approximately $\$ 1277$ per person (Queensland 
Treasury, 2021). In the same period, electronic gaming machines accounted for approximately \$12.7 billion in gambler losses (Queensland Treasury, 2021). In the Australian state of Victoria alone, the social costs of gambling per year is estimated to be around $\$ 7$ billion (Browne et al., 2017). Second, the prevalence of financial stress is also high in Australia. A recent survey by the Melbourne Institute shows that between September to November 2020, overall financial stress among Australians was between 54.9 to $61.5 \%$ in regions with lowest (Quartile 1) and highest (Quartile 4) poverty rates respectively (Broadway et al., 2020). This makes Australia an ideal context to examine the impact of gambling on financial stress.

We contribute to a small body of literature that has examined the impact of gambling on financial wellbeing, such as loss of savings and overindebtedness (see, e.g., Darbyshire et al., 2001; Mathews \& Volberg, 2013; Patford, 2007). Studies in this literature are mostly qualitative and show that gambling has financial implications, with consequences for families as well. Our study also relates to Watanapongvanich et al. (2020), which is the only study of which we are aware that examines the impact of financial literacy on gambling. Using data from Japan, Watanapongvanich et al. (2020) show that financial literacy is negatively associated with gambling frequency, and thus, the issue of problem gambling can be addressed by promoting financial literacy. Our study differs given that we do not examine the direct effect of financial literacy on gambling but the moderating role of financial resilience in the gambling-financial stress relationship. Financial literacy can help to reduce the potential stress associated with problem gambling because existing studies have shown that financial literacy enhances financial resilience (Klapper \& Lusardi, 2020; Lusardi et al., 2020). Similarly, financial literacy helps to build financial resilience by increasing financial inclusion (Klapper \& Lusardi, 2020; Koomson et al., 2020a). This is because some studies have shown that financial inclusion enhances financial resilience (Belayeth Hussain et al., 2019; Koomson et al., 2020b). ${ }^{1}$ Our study also complements the literature that examines the impact of other addictive behaviour, such as smoking, on financial stress (Siahpush et al., 2003, 2007; Widome et al., 2015). Findings from these studies suggest that smoking is associated with a higher probability of financial stress even after accounting for other factors. We complement these studies by providing new insights on gambling, which is a dimension of addictive behaviour that has not received much attention in the literature. Our paper also relates to studies that examine financial stress as an antecedent to addictive behaviour (see, e.g., Dobson, 2004; Graham, 1993; Siahpush \& Carlin, 2006). This literature suggests that people tend towards addictive behaviours, such as gambling, as a way of alleviating financial hardship.

\section{Data and Variables}

We use data drawn from the HILDA Survey, an Australian household panel survey that reports on household demographics, family, income and labour market outcomes, among others. The survey is nationally representative and has been administered yearly since 2001 (Watson \& Wooden, 2012). To date, the survey has produced 19 annual waves of data,

\footnotetext{
${ }^{1}$ Financial literacy refers to the ability to make informed judgements and decisions regarding the use and management of money (Widdowson \& Hailwood, 2007).

Financial inclusion is the supply of usable and cheap financial products and services that serve the needs of individuals and business in responsible and sustainable manner (World Bank, 2018).
} 
although only waves 15 and 18 provide information on gambling. Thus, we use only waves 15 and 18 for our empirical analysis. HILDA data are mainly collected through face-toface interviews, with some modules administered via self-completion questionnaires. In a few instances, telephone and assisted interviews are conducted for households that moved from their originally selected areas to ensure high response rates. Data collection for waves 15 and 18 were respectively undertaken in 2015 and 2018. The sample sizes for waves 15 and 18 are 23,305 and 23,259, respectively, which gives us panel data with a sample size of 46,564 . Since the gambling questions were posed to those aged 15 years and above, we have a workable sample of 37,020 . Due to missing observations, the regression analysis with the highest observations includes 30,728 individuals.

\subsection{Gambling}

In waves 15 and 18 of the HILDA survey, respondents were asked a set of questions relating to gambling participation and expenditures that allows us to employ various indicators of gambling behaviour. Our main gambling measure is based on the PGSI, which captures problem gambling severity (Currie et al., 2013; Ferris \& Wynne, 2001; Jackson et al., 2010). The PGSI is a validated measure of gambling behaviour widely used in the literature to assess the severity of problem gambling in population-based samples (see, e.g., Awaworyi Churchill \& Farrell, 2019, 2020a; Gong \& Zhu, 2019; Holtgraves, 2008; Korman et al., 2008; Loo et al., 2011; Raisamo et al., 2014). To derive the PGSI scores, we use information from a nine-item questionnaire that captures problem gambling behaviour and the adverse effects of gambling experienced in the 12 months before the survey interview. A four-point scale is used to rate responses on the nine items (see, Table 12), where 0 and 3 denote 'never' and 'almost always', respectively. Responses from the questionnaire are summed, giving PGSI scores ranging from 0 to 27. The higher the PGSI scores, the greater the severity of gambling problems.

We also capture gamblers' risk status using their PGSI scores. We identify four risk statuses: (1) non-problem gamblers (i.e., those who did not engage in any problem gambling behaviour or never experienced the detrimental effects of gambling over the past year, and hence have a PGSI score of 0); (2) low-risk gamblers (i.e., those with PGSI scores of 1 or 2); (3) moderate-risk gamblers (i.e., those with PGSI scores of 3 to 7); and (4) problem gamblers (i.e., those with PGSI scores of at least 8). From these risk statuses, we create a four-point ordinal scale, which captures these risk statuses, where 1 denotes 'non-problem gamblers', 2 denotes 'low-risk gamblers', 3 denotes 'moderate-risk gamblers', and 4 denotes 'problem gamblers'. A movement up the scale reflects higher gambling risk.

To assess the relationship between gambling participation/engagement and financial stress, we employ gambling participation measures, such as number of gambling activities in which respondents engage on a monthly basis, average monthly expenditure on gambling and binary variables for each gambling activity including scratch cards, electronic gaming machines, casinos and others. In robustness checks, we use binary variables corresponding to each of the gambling risk statuses.

\subsection{Financial Stress}

We combine the approaches employed in previous studies to generate four binary measures of financial stress using the section of the HILDA survey that captures information on respondents' experiences of financial stress and economic hardship. Based on a 
self-completion questionnaire, respondents were asked whether they experienced any of the following over the past 12 months: (1) "could not pay electricity, gas or telephone bills on time", (2) "could not pay the mortgage or rent on time", (3) "pawned or sold something", (4) "went without meals", (5) "was unable to heat home", (6) "asked for financial help from friends or family", and (7) "asked for help from welfare/community organisations". From these questions, we generate and label our four indicators as 'financial difficulty', 'cashflow', 'hardship' and 'any stress'.

The first measure, labelled 'financial difficulty' follows Wilkins and Lass (2015), who suggest that two or more of the seven conditions must be experienced for a person or household to be classified as being financially stressed. The other three indicators are consistent with the literature that focuses on specific indicators of financial stress (Bray, 2001; Breunig \& Cobb-Clark, 2006; Breunig et al., 2019). We generate 'cashflow' from the three indicators that are related to cash flow problems (inability to pay rent/mortgage, inability to pay utilities, and borrowing from friends) (Breunig \& Cobb-Clark, 2006; Breunig et al., 2019). 'Hardship' is measured using the four indicators that connote financial hardship (missing meals, pawning something, inability to heat the home and applying for welfare) while 'any stress' is generated from an experience of at last one of the seven indicators of financial stress (Breunig \& Cobb-Clark, 2006; Breunig et al., 2019). For the robustness check, we sum up affirmative responses for all seven questions to generate an additive index of financial stress that ranges from 0 to 7 . A higher value reflects higher financial stress (Breunig \& Cobb-Clark, 2006; Breunig et al., 2019).

\subsection{Financial Resilience}

Financial resilience is conceptualised as the ability to come up with an emergency fund equal to one year of income (see, e.g., Demirgüç-Kunt et al., 2020; Klapper \& Lusardi, 2020; Lusardi et al., 2020). Although the time frame may vary, respondents in the Global Findex survey were asked if it was possible for them to come up with an amount equal to $1 / 20$ of gross national income per capita in local currency within the next month (Demirgüç-Kunt et al., 2020). The study by Lusardi et al. (2020) also used a time frame of one month. In the HILDA survey, respondents were asked: "Suppose you had only one week to raise $\$ 2000$ for an emergency. Which of the following best describes how hard it would be for you to get that money?" The possible answers to the question were " $1=$ Could easily raise emergency funds"; " $2=$ Could raise emergency funds, but it would involve some sacrifices"; " $3=$ Would have to do something drastic to raise emergency funds"; and $4=$ Couldn't raise emergency funds". Participants also had the option of refusing to answer. Respondents who selected either of the first two options are considered financially resilient and coded 1 while any of the last two were coded 0 to indicate that they are financially nonresilient or fragile (Lusardi et al., 2020).

\subsection{Covariates}

We include a set of covariates that is consistent with the literature on the determinants of financial stress (Bray, 2001; Breunig \& Cobb-Clark, 2006; Breunig et al., 2019). This includes age; gender (binary variable for 'female'); employment status (binary variables for 'employed' using 'unemployed/not in labour force' as the base category); log of disposable income; marital status (binary variables for 'married', 'de facto relationship', 'separated', 'divorced', 'widowed' using 'single' as the base category); educational status 
(binary variables for 'postgraduate', 'graduate diploma', 'bachelor/honours', 'diploma', 'certificate' and 'year 12' using 'year 11 or below' as the base category); disability status (binary variable for 'long-term illness/disability'); household size; and homeownership status (binary variable for 'outright owners'). Based on existing literature (Bray, 2001; Breunig \& Cobb-Clark, 2006; Breunig et al., 2019), we expect presence of a child in the house and long-term illness to be positively associated with financial stress while education, and outright home ownership are expected to be negatively associated with financial stress. An increase in household size is expected to increase financial stress while a unit increase in age and employment income is expected to decrease financial stress. Financial stress is expected to be more prevalent among females while different marital statuses are expected to have varied associations with financial stress.

Table 13 in the appendix presents a description and summary statistics of the variables included in the analysis.

\section{Estimation Strategy}

Our baseline estimates are based on a model for financial stress as follows:

$$
\text { Fstress }_{i t}=\beta_{1} G B_{i t}+\sum_{n} \beta_{n} X_{n, i t}+\alpha_{s}+\mu_{t}+\varepsilon_{i t}
$$

where Fstress $_{i t}$ is the measure of financial stress for respondent $i$ at time $t$; and $G B$ is the indicator of gambling behaviour; $X$ is a set of covariates likely to influence financial stress; $\alpha_{s}$ and $\mu_{t}$ respectively represent state and wave fixed effects, while $\varepsilon$ is the error term. For our baseline results, we use ordinary least squares (OLS).

In the gambling-financial stress relationship, gambling is likely to be endogenous (Awaworyi Churchill \& Farrell, 2019, 2020a). While we examine the impact of gambling on financial stress, it is also likely that financial stress can cause people to gamble (Buchanan et al., 2020), thus raising the issue of reverse causality, which may be a source of endogeneity bias. Endogeneity may also arise due to unobserved factors or omitted variable bias, which we are unable to control for but are likely to influence both individual problem gambling severity and financial stress. One way to address the endogeneity problem is to use the lag of PGSI. On the one hand, problem gambling severity in the previous period is expected to influence financial stress in the current period. On the other hand, we do not expect financial stress in the current period to influence gambling decisions in the past, which resolves the reverse causality problem but not the omitted variable bias. However, endogeneity can also be addressed using a two-stage least squares (2SLS) method in which an external instrument is employed. The 2SLS approach, as used widely in the literature (Awaworyi Churchill \& Farrell, 2019, 2020a; Koomson \& Danquah, 2021), is capable of addressing endogeneity emanating from both reverse causality and omitted variable bias. On this basis, we address endogeneity in this paper using the 2SLS method, where we instrument for problem gambling severity using the number of gamblers in respondents' neighbourhoods but not including the respondents' households.

A number of studies have identified the role of social influence on gambling behaviour (see, e.g., Dahl et al., 2018; Russell et al., 2018; Saugeres et al., 2012). For instance, Russell et al. (2018) found that people with high risk of gambling were surrounded by significantly more gamblers. Russell et al. (2018) indicate that, passively or actively, the social influence in relation to gambling could be one of four types: early socialisation into gambling, social/peer norms, social selection, and social influence while gambling. Thus, an 
Table 1 Gambling and financial stress (Baseline Results)

\begin{tabular}{lllll}
\hline Variables & $\begin{array}{l}\text { Financial difficulty } \\
(1)\end{array}$ & $\begin{array}{l}\text { Cashflow } \\
(2)\end{array}$ & $\begin{array}{l}\text { Hardship } \\
(3)\end{array}$ & $\begin{array}{l}\text { Any stress } \\
(4)\end{array}$ \\
\hline Panel A: Model for PGSI & & & & \\
PGSI & $\mathbf{0 . 0 1 8 * * *}$ & $\mathbf{0 . 0 2 1} * * *$ & $\mathbf{0 . 0 1 5} * * *$ & $\mathbf{0 . 0 2 1} * * *$ \\
& $(0.002)$ & $(0.002)$ & $(0.002)$ & $(0.002)$ \\
& {$[\mathbf{0 . 0 8 6}]$} & {$[\mathbf{0 . 0 8 4}]$} & {$[\mathbf{0 . 0 7 5}]$} & {$[\mathbf{0 . 0 8 0}]$} \\
Controls & Yes & Yes & Yes & Yes \\
Wave fixed effect & Yes & Yes & Yes & Yes \\
State fixed effect & Yes & Yes & Yes & Yes \\
Observations & 30,728 & 30,728 & 30,728 & 30,728 \\
R-squared & 0.097 & 0.103 & 0.098 & 0.118 \\
Panel B: Model for risk status & & & \\
Gambling risk status & $\mathbf{0 . 0 5 7 * * *}$ & $\mathbf{0 . 0 6 9 * * *}$ & $\mathbf{0 . 0 4 8} * * *$ & $\mathbf{0 . 0 7 1 * * *}$ \\
& $(0.005)$ & $(0.006)$ & $(0.005)$ & $(0.006)$ \\
& {$[\mathbf{0 . 0 8 2}]$} & {$[\mathbf{0 . 0 8 3}]$} & {$[\mathbf{0 . 0 7 3}]$} & {$[\mathbf{0 . 0 8 1}]$} \\
Controls & Yes & Yes & Yes & Yes \\
Wave fixed effect & Yes & Yes & Yes & Yes \\
State fixed effect & Yes & Yes & Yes & Yes \\
Observations & 30,728 & 30,728 & 30,728 & 30,728 \\
R-squared & 0.096 & 0.103 & 0.098 & 0.118 \\
\hline
\end{tabular}

Robust standard errors in parentheses $* * * p<0.01, * * p<0.05, * p<0.1$

Standardised coefficients in square brackets

individual living in a neighbourhood with more gamblers is likely to develop a gambling behaviour and spend more on gambling-related activities. The exclusion restriction is that while we expect a direct relationship between the number of gamblers in a respondent's neighbourhood and their gambling behaviour, the only channel through which the number of gamblers in the respondent's neighbourhood is likely to influence financial stress is through the respondent's gambling activity. Thus, number of gamblers in a respondent's neighbourhood should not be directly correlated with the financial stress of individuals unless through their own gambling activity.

\section{Results}

\subsection{Baseline Results}

Table 1 presents the baseline estimates for the association between problem gambling severity (measured using the PGSI and gambling risk status) and the four indicators of financial stress, including financial difficulty, cashflow problems, financial hardship and 
any financial stress. ${ }^{2}$ Panel A reports results for the effects of PGSI, while Panel B reports results for gambling risk status using the ordinal scale. The results from both panels indicate that problem gambling severity has a positive and statistically significant effect on self-reported financial stress. From Columns 1 to 4 of Panel A, we find that a standard deviation increase in PGSI is associated with a: (1) 0.086 standard deviation increase in financial difficulty, (2) 0.084 standard deviation increase in having a cashflow problem, (3) 0.075 standard deviation increase in experiencing financial hardship, and (4) 0.080 standard deviation increase in the experience of any financial stress. Similarly, from Panel B, we find that a standard deviation increase in gambling risk is linked to a: (1) 0.082 standard deviation increase in financial difficulty, (2) 0.083 standard deviation increase in having a cash flow problem, (3) 0.073 standard deviation increase in experiencing financial hardship, and (4) 0.081 standard deviation increase in the experience of any financial stress. Our results are in line with the anecdotes that point to a positive association between gambling and financial stress (Central Coast Gambling Help, 2017; Dickson-Swift et al., 2005).

The effects of the control variables are consistent with expectations and the literature. Specifically, as shown in Tables 15 and 16, higher levels of education (e.g., bachelor, graduate diploma and postgraduate), being employed, married and having a disposable income are associated with lower financial stress levels (Breunig \& Cobb-Clark, 2006; Breunig et al., 2019). On the contrary, being female, living with disability, and having a dependant increase financial stress (Breunig et al., 2019).

\subsection{SLS estimates}

Table 2 reports the 2SLS results using number of gamblers in respondents' neighbourhoods as an instrument. Consistent with expectations, we find that the number of gamblers in respondents' neighbourhoods is positively associated with problem gambling severity. The first stage F statistics across all regression outputs are greater than the threshold of 10 , which implies that our instruments are not weakly correlated with problem gambling severity (Stock \& Yogo, 2005). We find that the 2SLS estimates are relatively larger than the baseline estimates in Table 1, which implies that endogeneity caused a downwards bias in the baseline estimates. From Panel A of Table 2, we find that a standard deviation increase in PGSI is associated with a: (1) 0.246 standard deviation increase in financial difficulty, (2) 0.194 standard deviation increase in having a cashflow problem, (3) 0.267 standard deviation increase in experiencing financial hardship, and (4) a 0.234 standard deviation increase in the experience of any financial stress. Similarly, from Panel B, we find that a standard deviation increase in gambling risk status is associated with a: (1) 0.195 standard deviation increase in financial difficulty, (2) 0.154 standard deviation increase in having a cashflow problem, (3) 0.212 standard deviation increase in experiencing financial hardship, and (4) 0.186 standard deviation increase in the experience of any financial stress.

\subsection{Gambling Participation/Engagement and Financial Stress}

In this section, we examine the link between gambling participation/engagement and financial stress using different gambling participation measures. First, we use the number of

\footnotetext{
2 The full set of results including all covariates for the effects of PGSI and gambling risk status are reported in Tables 15 and 16, respectively.
} 
Table 2 Gambling and financial stress (2SLS results)

\begin{tabular}{|c|c|c|c|c|}
\hline Variables & $\begin{array}{l}\text { Financial stress } \\
\text { (1) }\end{array}$ & $\begin{array}{l}\text { Cashflow } \\
\text { (2) }\end{array}$ & $\begin{array}{l}\text { Hardship } \\
\text { (3) }\end{array}$ & $\begin{array}{l}\text { Any stress } \\
\text { (4) }\end{array}$ \\
\hline \multicolumn{5}{|l|}{ Panel A: Model for PGSI } \\
\hline \multirow[t]{3}{*}{ PGSI } & $0.052 * * *$ & $0.049 * * *$ & $0.054 * * *$ & $0.062 * * *$ \\
\hline & $(0.015)$ & $(0.018)$ & $(0.014)$ & $(0.019)$ \\
\hline & {$[0.246]$} & {$[0.194]$} & {$[0.267]$} & {$[0.234]$} \\
\hline Controls & Yes & Yes & Yes & Yes \\
\hline Wave fixed effect & Yes & Yes & Yes & Yes \\
\hline State fixed effect & Yes & Yes & Yes & Yes \\
\hline Observations & 30,728 & 30,728 & 30,728 & 30,728 \\
\hline \multicolumn{5}{|l|}{ First stage } \\
\hline \multirow[t]{2}{*}{ Number of gamblers in neighbourhood } & $0.297 * * *$ & $0.297 * * *$ & $0.297 * * *$ & $0.297 * * *$ \\
\hline & $(0.029)$ & $(0.029)$ & $(0.029)$ & $(0.029)$ \\
\hline R-squared & 0.024 & 0.024 & 0.024 & 0.024 \\
\hline F-statistics of first stage & 101.89 & 101.89 & 101.89 & 101.89 \\
\hline \multicolumn{5}{|l|}{ Panel B: Model for risk status } \\
\hline \multirow[t]{3}{*}{ Gambling risk status } & $0.136 * * *$ & $0.128 * * *$ & $0.140 * * *$ & $0.163 * * *$ \\
\hline & $(0.040)$ & $(0.046)$ & $(0.037)$ & $(0.048)$ \\
\hline & {$[0.195]$} & {$[0.154]$} & {$[0.212]$} & {$[0.186]$} \\
\hline Controls & Yes & Yes & Yes & Yes \\
\hline Wave fixed effect & Yes & Yes & Yes & Yes \\
\hline State fixed effect & Yes & Yes & Yes & Yes \\
\hline Observations & 30,728 & 30,728 & 30,728 & 30,728 \\
\hline \multicolumn{5}{|l|}{ First stage } \\
\hline \multirow[t]{2}{*}{ Number of gamblers in neighbourhood } & $0.114 * * *$ & $0.114 * * *$ & $0.114 * * *$ & $0.114 * * *$ \\
\hline & $(0.009)$ & $(0.009)$ & $(0.009)$ & $(0.009)$ \\
\hline R-squared & 0.034 & 0.034 & 0.034 & 0.034 \\
\hline F-statistic of first stage & 157.70 & 157.70 & 157.70 & 157.70 \\
\hline
\end{tabular}

Robust standard errors in parentheses $* * * p<0.01, * * p<0.05, * p<0.1$

Standardised coefficients in square brackets

gambling activities respondents engage in and present the results in Table 3. From Columns 1 to 4, we observe that a standard deviation increase in the number of gambling activities is associated with a: (1) 0.264 standard deviation increase in financial difficulty, (2) 0.208 standard deviation increase in having a cashflow problem, (3) 0.297 standard deviation increase in experiencing financial hardship, and (4) a 0.261 standard deviation increase in the experience of any financial stress. Second, we use gambling expenditure to explore the gambling-financial stress nexus and present the results in Table 4. In Columns 1 to 4 , we observe that a standard deviation increase in gambling expenditure is linked to a: (1) 0.282 standard deviation increase in financial difficulty, (2) 0.221 standard deviation increase in having a cashflow problem, (3) 0.317 standard deviation increase in experiencing financial hardship, and (4) a 0.279 standard deviation increase in the experience of any financial stress.

Third, we use binary variables capturing different gambling activities as alternative measures of gambling participation. We focus on gambling activities including scratch 
Table 3 Number of gambling activities (additive index) and financial stress

\begin{tabular}{lllll}
\hline Variables & $\begin{array}{l}\text { Financial stress } \\
(1)\end{array}$ & $\begin{array}{l}\text { Cashflow } \\
(2)\end{array}$ & $\begin{array}{l}\text { Hardship } \\
(3)\end{array}$ & $\begin{array}{l}\text { Any stress } \\
(4)\end{array}$ \\
\hline Number of gambling activities & $\mathbf{0 . 0 7 8} * * *$ & $\mathbf{0 . 0 7 3}^{* * *}$ & $\mathbf{0 . 0 8 3} * * *$ & $\mathbf{0 . 0 9 7 * * *}$ \\
& $(0.025)$ & $(0.028)$ & $(0.024)$ & $(0.030)$ \\
& {$[\mathbf{0 . 2 6 4}]$} & {$[\mathbf{0 . 2 0 8}]$} & {$[\mathbf{0 . 2 9 7}]$} & {$[\mathbf{0 . 2 6 1}]$} \\
Controls & Yes & Yes & Yes & Yes \\
Wave fixed effect & Yes & Yes & Yes & Yes \\
State fixed effect & Yes & Yes & Yes & Yes \\
Observations & 30,745 & 30,745 & 30,745 & 30,745 \\
First stage & & & & \\
Number of gamblers in neighbourhood & $0.187 * * *$ & $0.187 * * *$ & $0.187 * * *$ & $0.187 * * *$ \\
& $(0.019)$ & $(0.019)$ & $(0.019)$ & $(0.019)$ \\
R-squared & 0.064 & 0.064 & 0.064 & 0.064 \\
F-statistic of first stage & 99.27 & 99.27 & 99.27 & 99.27 \\
\hline
\end{tabular}

Robust standard errors in parentheses $* * * p<0.01, * * p<0.05, * p<0.1$

Standardised coefficients in square brackets

Table 4 Gambling expenditure and financial stress

\begin{tabular}{lllll}
\hline Variables & $\begin{array}{l}\text { Financial stress } \\
(1)\end{array}$ & $\begin{array}{l}\text { Cashflow } \\
(2)\end{array}$ & $\begin{array}{l}\text { Hardship } \\
(3)\end{array}$ & $\begin{array}{l}\text { Any stress } \\
(4)\end{array}$ \\
\hline $\log ($ Gambling expenditure $)$ & $\mathbf{0 . 0 4 6 * * *}$ & $\mathbf{0 . 0 4 3}^{* *}$ & $\mathbf{0 . 0 4 9} * * *$ & $\mathbf{0 . 0 5 7} * * *$ \\
& $(0.015)$ & $(0.017)$ & $(0.014)$ & $(0.018)$ \\
& {$[\mathbf{0 . 2 8 2}]$} & {$[\mathbf{0 . 2 2 1}]$} & {$[\mathbf{0 . 3 1 7}]$} & {$[\mathbf{0 . 2 7 9}]$} \\
Controls & Yes & Yes & Yes & Yes \\
Wave fixed effect & Yes & Yes & Yes & Yes \\
State fixed effect & Yes & Yes & Yes & Yes \\
Observations & 30,692 & 30,692 & 30,692 & 30,692 \\
First Stage & & & & \\
Number of gamblers in neighbourhood & $0.316^{* * *}$ & $0.316^{* * * *}$ & $0.316^{* * * *}$ & $0.316^{* * *}$ \\
& $(0.029)$ & $(0.029)$ & $(0.029)$ & $(0.029)$ \\
R-squared & 0.103 & 0.103 & 0.103 & 0.103 \\
F-statistic of first stage & 117.50 & 117.50 & 117.50 & 117.50 \\
\hline
\end{tabular}

Robust standard errors in parentheses $* * * p<0.01, * * p<0.05, * p<0.1$

Standardised coefficients in square brackets

tickets, Bingo, lotto or lottery games, Keno, private betting, poker, casino table games, poker machines, horse and dog race betting, and sports betting. The results, which are reported in Table 5, reveal three main findings: (1) engaging in gambling activities 
Table 5 Different gambling activities and financial stress

\begin{tabular}{|c|c|c|c|c|}
\hline Variables & $\begin{array}{l}\text { Financial stress } \\
\text { (1) }\end{array}$ & $\begin{array}{l}\text { Cashflow } \\
\text { (2) }\end{array}$ & $\begin{array}{l}\text { Hardship } \\
\text { (3) }\end{array}$ & $\begin{array}{l}\text { Any stress } \\
\text { (4) }\end{array}$ \\
\hline \multicolumn{5}{|l|}{ Panel A: Scratch tickets } \\
\hline \multirow{3}{*}{ Scratch tickets $(0 / 1)$} & $0.019 * *$ & $0.033 * * *$ & 0.011 & $0.033 * * *$ \\
\hline & $(0.007)$ & $(0.009)$ & $(0.007)$ & $(0.009)$ \\
\hline & {$[0.015]$} & {$[0.022]$} & {$[0.009]$} & {$[0.021]$} \\
\hline All controls & Yes & Yes & Yes & Yes \\
\hline Observations & 30,581 & 30,581 & 30,581 & 30,581 \\
\hline R-squared & 0.089 & 0.097 & 0.093 & 0.112 \\
\hline \multicolumn{5}{|l|}{ Panel B: Bingo } \\
\hline \multirow[t]{3}{*}{ Bingo $(0 / 1)$} & 0.013 & 0.031 & 0.015 & 0.022 \\
\hline & $(0.019)$ & $(0.021)$ & $(0.018)$ & $(0.022)$ \\
\hline & {$[0.004]$} & [0.009] & {$[0.005]$} & {$[0.006]$} \\
\hline All controls & Yes & Yes & Yes & Yes \\
\hline Observations & 30,486 & 30,486 & 30,486 & 30,486 \\
\hline R-squared & 0.089 & 0.096 & 0.093 & 0.112 \\
\hline \multicolumn{5}{|l|}{ Panel C: Lotto or lottery games } \\
\hline \multirow[t]{3}{*}{ Lotto or lottery games $(0 / 1)$} & $-0.008 * *$ & -0.006 & -0.006 & -0.005 \\
\hline & $(0.004)$ & $(0.005)$ & $(0.004)$ & $(0.005)$ \\
\hline & {$[-0.011]$} & {$[-0.007]$} & {$[-0.008]$} & {$[-0.005]$} \\
\hline All controls & Yes & Yes & Yes & Yes \\
\hline Observations & 30,647 & 30,647 & 30,647 & 30,647 \\
\hline R-squared & 0.089 & 0.096 & 0.093 & 0.112 \\
\hline \multicolumn{5}{|l|}{ Panel D: Keno } \\
\hline \multirow[t]{3}{*}{ Keno $(0 / 1)$} & 0.002 & 0.007 & -0.009 & 0.000 \\
\hline & $(0.010)$ & $(0.012)$ & $(0.009)$ & $(0.012)$ \\
\hline & {$[0.001]$} & {$[0.004]$} & {$[-0.006]$} & {$[0.001]$} \\
\hline All controls & Yes & Yes & Yes & Yes \\
\hline Observations & 30,381 & 30,381 & 30,381 & 30,381 \\
\hline R-squared & 0.089 & 0.096 & 0.093 & 0.112 \\
\hline \multicolumn{5}{|l|}{ Panel E: Private betting } \\
\hline \multirow[t]{3}{*}{ Private betting $(0 / 1)$} & 0.024 & 0.033 & 0.023 & 0.026 \\
\hline & $(0.017)$ & $(0.021)$ & $(0.017)$ & $(0.021)$ \\
\hline & {$[0.008]$} & {$[0.010]$} & {$[0.008]$} & {$[0.007]$} \\
\hline All controls & Yes & Yes & Yes & Yes \\
\hline Observations & 30,543 & 30,543 & 30,543 & 30,543 \\
\hline R-squared & 0.089 & 0.096 & 0.093 & 0.112 \\
\hline \multicolumn{5}{|l|}{ Panel F: Poker } \\
\hline \multirow[t]{3}{*}{ Poker (0/1) } & 0.021 & 0.022 & 0.025 & 0.016 \\
\hline & $(0.018)$ & $(0.021)$ & $(0.017)$ & $(0.022)$ \\
\hline & {$[0.007]$} & {$[0.006]$} & [0.009] & {$[0.004]$} \\
\hline All controls & Yes & Yes & Yes & Yes \\
\hline Observations & 30,523 & 30,523 & 30,523 & 30,523 \\
\hline R-squared & 0.089 & 0.096 & 0.093 & 0.112 \\
\hline
\end{tabular}


Table 5 (continued)

\begin{tabular}{|c|c|c|c|c|}
\hline Variables & $\begin{array}{l}\text { Financial stress } \\
\text { (1) }\end{array}$ & $\begin{array}{l}\text { Cashflow } \\
\text { (2) }\end{array}$ & $\begin{array}{l}\text { Hardship } \\
\text { (3) }\end{array}$ & $\begin{array}{l}\text { Any stress } \\
\text { (4) }\end{array}$ \\
\hline \multicolumn{5}{|l|}{ Panel G: Casino table games } \\
\hline \multirow[t]{3}{*}{ Casino table games $(0 / 1)$} & 0.015 & 0.028 & 0.024 & 0.027 \\
\hline & $(0.017)$ & $(0.020)$ & $(0.016)$ & $(0.021)$ \\
\hline & {$[0.005]$} & {$[0.008]$} & {$[0.009]$} & {$[0.007]$} \\
\hline All controls & Yes & Yes & Yes & Yes \\
\hline Observations & 30,550 & 30,550 & 30,550 & 30,550 \\
\hline R-squared & 0.089 & 0.096 & 0.093 & 0.112 \\
\hline \multicolumn{5}{|l|}{ Panel H: Poker machines } \\
\hline \multirow[t]{3}{*}{ Poker Machines $(0 / 1)$} & 0.014* & $0.027 * * *$ & -0.003 & $0.020 * *$ \\
\hline & $(0.007)$ & $(0.008)$ & $(0.006)$ & $(0.008)$ \\
\hline & {$[0.011]$} & {$[0.019]$} & {$[-0.003]$} & {$[0.013]$} \\
\hline All controls & Yes & Yes & Yes & Yes \\
\hline Observations & 30,580 & 30,580 & 30,580 & 30,580 \\
\hline R-squared & 0.089 & 0.096 & 0.093 & 0.112 \\
\hline \multicolumn{5}{|l|}{ Panel I: Race: horse and dogs betting } \\
\hline \multirow[t]{3}{*}{ Race: horse and dogs betting (0/1) } & $-0.014 * *$ & 0.001 & $-0.017 * * *$ & -0.008 \\
\hline & $(0.007)$ & $(0.009)$ & $(0.006)$ & $(0.009)$ \\
\hline & {$[-0.010]$} & {$[0.000]$} & {$[-0.013]$} & {$[-0.005]$} \\
\hline All controls & Yes & Yes & Yes & Yes \\
\hline Observations & 30,586 & 30,586 & 30,586 & 30,586 \\
\hline R-squared & 0.089 & 0.096 & 0.093 & 0.111 \\
\hline \multicolumn{5}{|l|}{ Panel J: Sports betting } \\
\hline \multirow[t]{3}{*}{ Sports betting $(0 / 1)$} & -0.006 & -0.002 & -0.009 & -0.014 \\
\hline & $(0.009)$ & $(0.011)$ & $(0.009)$ & $(0.012)$ \\
\hline & {$[-0.004]$} & {$[-0.001]$} & {$[-0.005]$} & {$[-0.007]$} \\
\hline All controls & Yes & Yes & Yes & Yes \\
\hline Observations & 30,534 & 30,534 & 30,534 & 30,534 \\
\hline R-squared & 0.089 & 0.096 & 0.093 & 0.112 \\
\hline
\end{tabular}

Robust standard errors in parentheses $* * * p<0.01, * * p<0.05, * p<0.1$

Standardised coefficients in square brackets

involving scratch cards and poker machines is associated with higher levels of financial stress, (2) horse and dog race betting is associated with lower financial stress, and (3) engaging in other gambling activities has no significant effect on financial stress. These suggest that the overall finding that gambling has a positive effect on financial stress is being driven by gambling activities involving scratch cards and poker machines.

\subsection{Gender Analysis}

Table 6 reports the gender differentials in mean values of financial stress and gambling measures. Panel A presents the mean financial difficulty and sample mean differences in financial stress, by gender. Panels B, C, D, E and F display similar statistics for cashflow 
Table 6 Gender differentials in proportions/mean values of financial stress and gambling

\begin{tabular}{|c|c|c|c|c|c|c|c|}
\hline Variables & Male & Female & Total & $\begin{array}{l}\text { Male-Female } \\
\text { gap }\end{array}$ & Type of test & Test score & $\begin{array}{l}\text { Male-Female } \\
\text { gap } \%\end{array}$ \\
\hline \multicolumn{8}{|c|}{ Panel A: Proportional differences in financial stress } \\
\hline Financial stress & $\begin{array}{l}0.106 \\
(0.003)\end{array}$ & $\begin{array}{l}0.128 \\
(0.003)\end{array}$ & $\begin{array}{l}0.118 \\
(0.002)\end{array}$ & $\begin{array}{l}-0.022 \\
(0.004)\end{array}$ & chi-square & $35.111^{* * *}$ & -18.562 \\
\hline Observations & 14,406 & 16,322 & 30,728 & & & & \\
\hline \multicolumn{8}{|c|}{ Panel B: Proportional differences in cashflow } \\
\hline Cashflow & $\begin{array}{l}0.163 \\
(0.003)\end{array}$ & $\begin{array}{l}0.192 \\
(0.003)\end{array}$ & $\begin{array}{l}0.179 \\
(0.002)\end{array}$ & $\begin{array}{l}-0.029 \\
(0.004)\end{array}$ & chi-square & $44.006 * * *$ & -16.258 \\
\hline Observations & 14,406 & 16,322 & 30,728 & & & & \\
\hline \multicolumn{8}{|c|}{ Panel C: Proportional differences in hardship } \\
\hline Hardship & $\begin{array}{l}0.099 \\
(0.002)\end{array}$ & $\begin{array}{l}0.108 \\
(0.002)\end{array}$ & $\begin{array}{l}0.104 \\
(0.002)\end{array}$ & $\begin{array}{l}-0.008 \\
(0.003)\end{array}$ & chi-square & $5.495 * *$ & -8.654 \\
\hline Observations & 14,406 & 16,322 & 30,728 & & & & \\
\hline \multicolumn{8}{|c|}{ Panel D: Proportional differences in any stress } \\
\hline Any stress & $\begin{array}{l}0.191 \\
(0.003)\end{array}$ & $\begin{array}{l}0.219 \\
(0.003)\end{array}$ & $\begin{array}{l}0.206 \\
(0.002)\end{array}$ & $\begin{array}{l}-0.027 \\
(0.005)\end{array}$ & chi-square & $35.117 * * *$ & -13.300 \\
\hline Observations & 14,406 & 16,322 & 30,728 & & & & \\
\hline \multicolumn{8}{|c|}{ Panel E: Mean different in PGSI } \\
\hline PGSI & $\begin{array}{l}0.390 \\
(0.015)\end{array}$ & $\begin{array}{l}0.187 \\
(0.009)\end{array}$ & $\begin{array}{l}0.282 \\
(0.009)\end{array}$ & $\begin{array}{l}0.203 \\
(0.017)\end{array}$ & t-test & $11.770 * * *$ & 71.875 \\
\hline Observations & 14,406 & 16,322 & 30,728 & & & & \\
\hline \multicolumn{8}{|c|}{ Panel F: Mean gambling risk } \\
\hline Gambling risk & $\begin{array}{l}1.158 \\
(0.004)\end{array}$ & $\begin{array}{l}1.082 \\
(0.003)\end{array}$ & $\begin{array}{l}1.118 \\
(0.003)\end{array}$ & $\begin{array}{l}0.077 \\
(0.005)\end{array}$ & t-test & $14.579 * * *$ & 6.860 \\
\hline Observations & 14,406 & 16,322 & 30,728 & & & & \\
\hline
\end{tabular}

Robust standard errors in parentheses $* * * \mathrm{p}<0.01, * * \mathrm{p}<0.05, * \mathrm{p}<0.1$

problems, financial hardship, any financial stress, PGSI and gambling risk status, respectively. The statistics from Table 6 (Panels A to D) show that, on average, females are more financially stressed than males. Specifically, females experience more financial difficulty, cashflow problems, financial hardship and any financial stress than males. The male-female differences in the mean values of financial stress are all statistically significant at the $1 \%$ significance level, with the exception of financial hardship which exhibits significance at 5\%. The statistics from Panels $\mathrm{E}$ and $\mathrm{F}$ show evidence of significant gender gaps in gambling behaviour. Specifically, males exhibit more problematic gambling severity than females. PGSI average values are 0.390 for males and 0.187 for females, whereas average values for gambling risk status are 1.158 for males and 1.082 for females.

Table 7 presents marginal effects for OLS estimates on the average change in financial stress indicators for males and females between 2015 and 2018. Panels A, B, C and D suggest that the gender gap in financial difficulty, cashflow problems, financial hardship and any financial stress, respectively, decreases over time. Specifically, financial difficulty among females, on average, decreased from 0.022 in 2015 to 0.021 in 2018, which is approximately $1.4 \%$ decrease in the gender gap, relative to the 2015 gap (see, Panel A). Cashflow problems of females, on average, declined from 0.032 to 0.031 over the period, 
Table 7 Gender gaps in financial stress

\begin{tabular}{|c|c|c|c|c|}
\hline Variables & Start year (2015) & End year (2018) & $\begin{array}{l}\text { Change between } 2015 \\
\text { and } 2018\end{array}$ & Percent \\
\hline \multicolumn{5}{|c|}{ Panel A: Financial difficulty } \\
\hline Female & $\begin{array}{l}0.022 * * * \\
(0.005)\end{array}$ & $\begin{array}{l}0.021 * * * \\
(0.005)\end{array}$ & -0.001 & -1.383 \\
\hline Controls & Yes & Yes & & \\
\hline Observations & 17,523 & 17,355 & & \\
\hline \multicolumn{5}{|c|}{ Panel B: Cashflow } \\
\hline Female & $\begin{array}{l}0.032 * * * \\
(0.006)\end{array}$ & $\begin{array}{l}0.031 * * * \\
(0.006)\end{array}$ & -0.001 & -2.821 \\
\hline Controls & Yes & Yes & & \\
\hline Observations & 17,523 & 17,355 & & \\
\hline \multicolumn{5}{|c|}{ Panel C: Hardship } \\
\hline Female & $\begin{array}{l}0.007 * \\
(0.004)\end{array}$ & $\begin{array}{l}0.004 \\
(0.004)\end{array}$ & -0.003 & -38.889 \\
\hline Controls & Yes & Yes & & \\
\hline Observations & 17,523 & 17,355 & & \\
\hline \multicolumn{5}{|c|}{ Panel D: Any stress } \\
\hline Female & $\begin{array}{l}0.030^{* * *} \\
(0.006)\end{array}$ & $\begin{array}{l}0.028 * * * \\
(0.006)\end{array}$ & -0.002 & -5.705 \\
\hline Controls & Yes & Yes & & \\
\hline Observations & 17,523 & 17,355 & & \\
\hline
\end{tabular}

Robust standard errors in parentheses $* * * p<0.01,{ }^{* *} p<0.05, * p<0.1$

representing a $2.8 \%$ decrease in gender gap (see, Panel B). In Panels C and D, the table shows that between 2015 and 2018, the gender gap in financial hardship and in any financial stress decreased by $38.9 \%$ and $5.7 \%$, respectively, relative to the 2015 gap. In Table 14 , we can see that the coefficients for PGSI and gambling risk status are larger in the female samples than they are in the male samples. This suggests that gambling increases financial stress more for females than for males. In sum, although the gender difference in financial stress is decreasing over time, gambling behaviour is capable of widening the gender gap in financial stress. Using the Chow test of differences in coefficients between models reported in Table 14 (Chow, 1960), we can see that the reported chi-square values are all significant at the $1 \%$ alpha level. This means that the estimated coefficients for problem gambling severity and gambling risk status across all columns are statistically different between male and female models.

\subsection{Robustness checks}

Here, we engage in sensitivity checks to test the robustness of our estimates. We use an additive index of financial stress and also analyse the data for different risk statuses. First, we use the number of affirmative responses for all seven items of financial stress (additive index) as an alternative measure of financial stress and report the results in Table 8. In Columns 1 and 2, we observe that a standard deviation increase in PGSI and gambling risk status are associated with 0.280 and 0.222 standard deviation increases in financial stress. 
Table 8 Gambling and financial stress (index)

\begin{tabular}{|c|c|c|}
\hline Variables & $\begin{array}{l}\text { Financial stress index } \\
\text { (1) }\end{array}$ & $\begin{array}{l}\text { Financial stress index } \\
\text { (2) }\end{array}$ \\
\hline PGSI & $\begin{array}{l}\mathbf{0 . 2 0 6} * * * \\
(0.053) \\
{[\mathbf{0 . 2 8 0}]}\end{array}$ & \\
\hline Gambling risk & & $\begin{array}{l}\mathbf{0 . 5 3 7} * * * \\
(0.136) \\
{[\mathbf{0 . 2 2 2}]}\end{array}$ \\
\hline Controls & Yes & Yes \\
\hline Wave fixed effect & Yes & Yes \\
\hline State fixed effect & Yes & Yes \\
\hline $\begin{array}{l}\text { Observations } \\
\text { First stage }\end{array}$ & 30,728 & 30,728 \\
\hline $\begin{array}{l}\text { Number of gamblers in } \\
\text { neighbourhood }\end{array}$ & $\begin{array}{l}0.297 * * * \\
(0.029)\end{array}$ & $\begin{array}{l}0.113 * * * \\
(0.009)\end{array}$ \\
\hline R-squared & 0.024 & 0.034 \\
\hline F-statistic of first stage & 101.89 & 157.70 \\
\hline
\end{tabular}

This confirms that the positive relationship between gambling and financial stress is robust to an alternative approach to measuring financial stress.

Second, we verify if our results are sensitive to different gambling risk statuses and present the results in Table 9. In each column, we use 'no-problem gambler' as the base or reference category to which other estimates are compared. In Column 1, we can see that low-risk gamblers, moderate-risk gamblers and problem gamblers experience financial difficulties that are $0.033,0.039$ and 0.069 standard deviations higher compared to those experienced by non-problem gamblers. In Column 2, we can see that compared to nonproblem gamblers, low-risk gamblers, moderate-risk gamblers and problem gamblers are $0.033,0.042$ and 0.068 standard deviations more likely to experience cash flow problems. In Column 3, we can see that low-risk gamblers, moderate-risk gamblers and problem gamblers experience financial hardship that are 0.033, 0.037 and 0.057 standard deviations higher compared to those experienced by non-problem gamblers. In Column 4 , we can see that compared to non-problem gamblers, low-risk gamblers, moderate-risk gamblers and problem gamblers are $0.036,0.045$ and 0.060 standard deviations more likely to experience any form of financial stress. These results are generally consistent with the finding that more severe problem gambling is associated with more intense financial stress.

\subsection{Potential mechanism analysis}

In this section, we consider the role of financial resilience in mediating the relationship between gambling and financial stress. To analyse this, we use the binary measure of financial resilience described in Sect. 2.3, where 1 represents 'financially resilient' and 0 represents 'not financially resilient or financially fragile'. Consistent with previous studies (see, e.g., Alesina \& Zhuravskaya, 2011; Awaworyi Churchill et al., 2019), we follow a two-step approach to test whether financial resilience serves as a potential channel. First, we test whether gambling is significantly associated with financial resilience. In Columns 1 and 2 of 
Table 9 Different risk statuses and financial stress

\begin{tabular}{|c|c|c|c|c|}
\hline Variables & $\begin{array}{l}\text { Financial difficulty } \\
\text { (1) }\end{array}$ & $\begin{array}{l}\text { Cashflow } \\
\text { (2) }\end{array}$ & $\begin{array}{l}\text { Hardship } \\
\text { (3) }\end{array}$ & $\begin{array}{l}\text { Any stress } \\
\text { (4) }\end{array}$ \\
\hline \multicolumn{5}{|c|}{ Gambling risk status (Base $=$ non-problem gambler) } \\
\hline \multirow[t]{3}{*}{ Low-risk gambler } & $0.055 * * *$ & $0.066 * * *$ & $0.052 * * *$ & $0.076 * * *$ \\
\hline & $(0.011)$ & $(0.012)$ & $(0.010)$ & $(0.012)$ \\
\hline & {$[0.033]$} & {$[\mathbf{0 . 0 3 3}]$} & {$[0.033]$} & {$[0.036]$} \\
\hline \multirow[t]{3}{*}{ Moderate-risk gambler } & $0.083 * * *$ & $0.104 * * *$ & $0.074 * * *$ & $0.119 * * *$ \\
\hline & $(0.014)$ & $(0.016)$ & $(0.014)$ & $(0.016)$ \\
\hline & {$[0.039]$} & {$[0.042]$} & {$[0.037]$} & {$[0.045]$} \\
\hline \multirow[t]{3}{*}{ Problem gambler } & $0.222 * * *$ & $0.259 * * *$ & $0.173 * * *$ & $0.242 * * *$ \\
\hline & $(0.026)$ & $(0.028)$ & $(0.025)$ & $(0.028)$ \\
\hline & [0.069] & {$[0.068]$} & {$[0.057]$} & {$[0.060]$} \\
\hline All controls & Yes & Yes & Yes & Yes \\
\hline Observations & 30,728 & 30,728 & 30,728 & 30,728 \\
\hline R-squared & 0.096 & 0.103 & 0.098 & 0.118 \\
\hline
\end{tabular}

Robust standard errors in parentheses $* * * p<0.01, * * p<0.05, * p<0.1$

Standardised coefficients in square brackets

Table 10 Effect of gambling on financial resilience

\begin{tabular}{lll}
\hline Variables & $\begin{array}{l}\text { Financial resilience } \\
(1)\end{array}$ & $\begin{array}{l}\text { Financial resilience } \\
(2)\end{array}$ \\
\hline PGSI & $\mathbf{- 0 . 0 1 4 * * *}$ & \\
& $(0.002)$ & \\
& {$[\mathbf{- 0 . 0 4 9}]$} & $\mathbf{- 0 . 0 4 6 * * *}$ \\
Gambling risk & & $(0.006)$ \\
& & {$[-\mathbf{0 . 0 5 1}]$} \\
All controls & Yes & Yes \\
Observations & 30,273 & 30,273 \\
R-squared & 0.226 & 0.226 \\
\hline
\end{tabular}

Robust standard errors in parentheses $* * * p<0.01$, $* * p<0.05,{ }^{*} p<0.1$ Standardised coefficients in square brackets

Table 10, we observe that a standard deviation increase in problem gambling severity is associated with 0.049 and 0.051 standard deviations decrease or weakening in financial resilience.

Second, we include financial resilience as an explanatory variable in the financial stress model and display the results in Table 11 . To be eligible as a potential channel/mediator, the coefficient of gambling must reduce in magnitude or be rendered statistically insignificant if financial resilience is added as an additional covariate (Koomson \& Awaworyi Churchill, 2021; Koomson \& Danquah, 2021). Since we report OLS estimates, the coefficients for comparison are drawn from Table 1 and reported in Panels $\mathrm{A}(2)$ and $\mathrm{B}(2)$ of Table 11. In Columns 1 to 4 of Panels A(1) and B(1), we find that the inclusion of financial resilience as a covariate in the gambling-financial stress models all result in a reduction in the magnitude 
Table 11 Effect of mechanism

\begin{tabular}{|c|c|c|c|c|}
\hline Variables & $\begin{array}{l}\text { Financial stress } \\
\text { (1) }\end{array}$ & $\begin{array}{l}\text { Cashflow } \\
\text { (2) }\end{array}$ & $\begin{array}{l}\text { Hardship } \\
\text { (3) }\end{array}$ & $\begin{array}{l}\text { Any stress } \\
\text { (4) }\end{array}$ \\
\hline \multicolumn{5}{|c|}{ Panel A(1): PGSI model } \\
\hline \multirow[t]{3}{*}{ PGSI } & $0.015 * * *$ & $0.018 * * *$ & $0.012 * * *$ & $0.017 * * *$ \\
\hline & $(0.002)$ & $(0.002)$ & $(0.002)$ & $(0.002)$ \\
\hline & {$[0.070]$} & {$[0.068]$} & {$[0.057]$} & {$[0.062]$} \\
\hline \multirow[t]{3}{*}{ Fin resilience } & $-0.279 * * *$ & $-0.321 * * *$ & $-0.240 * * *$ & $-0.356 * * *$ \\
\hline & $(0.006)$ & $(0.007)$ & $(0.006)$ & $(0.007)$ \\
\hline & {$[-0.360]$} & {$[-0.348]$} & {$[-0.326]$} & {$[-0.365]$} \\
\hline All controls & Yes & Yes & Yes & Yes \\
\hline Observations & 30,273 & 30,273 & 30,273 & 30,273 \\
\hline R-squared & 0.197 & 0.197 & 0.181 & 0.221 \\
\hline \multicolumn{5}{|c|}{ Panel A(2): Baseline results for comparison } \\
\hline \multirow[t]{3}{*}{ PGSI } & $0.018 * * *$ & $0.021 * * *$ & $0.015 * * *$ & $0.021 * * *$ \\
\hline & $(0.002)$ & $(0.002)$ & $(0.002)$ & $(0.002)$ \\
\hline & {$[0.086]$} & {$[0.084]$} & {$[0.075]$} & {$[0.080]$} \\
\hline \multicolumn{5}{|c|}{ Panel B(1): Gamnbling risk model } \\
\hline \multirow[t]{3}{*}{ Gambling risk } & $0.044 * * *$ & $0.054 * * *$ & $0.036 * * *$ & $0.054 * * *$ \\
\hline & $(0.005)$ & $(0.005)$ & $(0.005)$ & $(0.005)$ \\
\hline & {$[0.063]$} & {$[0.064]$} & {$[0.054]$} & {$[0.061]$} \\
\hline \multirow[t]{3}{*}{ Financial resilience } & $-0.280 * * *$ & $-0.321 * * *$ & $-0.240 * * *$ & $-0.356 * * *$ \\
\hline & $(0.006)$ & $(0.007)$ & $(0.006)$ & $(0.007)$ \\
\hline & {$[-0.361]$} & {$[-0.348]$} & {$[-0.327]$} & {$[-0.365]$} \\
\hline All controls & Yes & Yes & Yes & Yes \\
\hline Observations & 30,273 & 30,273 & 30,273 & 30,273 \\
\hline R-squared & 0.196 & 0.196 & 0.180 & 0.221 \\
\hline \multicolumn{5}{|c|}{ Panel B (2): Baseline results for comparison } \\
\hline \multirow[t]{3}{*}{ PGSI } & $0.057 * * *$ & $0.069 * * *$ & $0.048 * * *$ & $0.071 * * *$ \\
\hline & $(0.005)$ & $(0.006)$ & $(0.005)$ & $(0.006)$ \\
\hline & {$[0.082]$} & {$[\mathbf{0 . 0 8 3}]$} & {$[\mathbf{0 . 0 7 3}]$} & {$[0.081]$} \\
\hline
\end{tabular}

Robust standard errors in parentheses $* * * p<0.01, * * p<0.05, * p<0.1$

Standardised coefficients in square brackets

of the coefficients of gambling (compared to those in Panels $A(2)$ and $B(2)$ ). The overall implication is that financial resilience serves as an important channel through which gambling influences financial stress. Put differently, gambling results in financial stress because it weakens financial resilience. Based on the expositions of the gambler's fallacy (Blaszczynski \& Nower, 2002; Tabri et al., 2022; Xu \& Harvey, 2014), which is associated with the loss chasing behaviours of gamblers, those who suffer from problem gambling severity are more likely to experience loss of savings and overindebtedness, which renders them financially fragile. Their inability to raise adequate funding in times of emergency also means that they are more likely to be financially stressed. Therefore, promoting policies such as financial literacy and financial inclusion (Klapper \& Lusardi, 2020; Lusardi et al., 2020) that are known to enhance financial resilience can help to insulate individuals and households against the debilitating effect of gambling on financial stress. 


\section{Conclusion}

In recent years, the socioeconomic cost of gambling has attracted the attention of policymakers and is now considered a significant public health concern. Although the adverse effects of gambling have also attracted the interest of researchers, little empirical evidence exists on the impact of gambling on financial stress. This study aimed at examining the link between individual problem gambling severity and self-reported financial stress to fill an important empirical gap. It also sought to ascertain whether there is a gender gap in financial stress and, if so, whether gambling narrows or widens this gap. Using data from the HILDA Survey, we achieved this objective across various measures of financial stress and gambling behaviour.

Gambling losses often lead to the depletion of financial and social resources. Victims of such losses are more likely to become financially fragile and find it difficult to raise emergency funds to smooth consumption in times of need. On the other hand, winners are likely to enjoy financial benefits that can help them raise emergency funds. After estimating various empirical models in which the endogeneity associated with problem gambling severity was addressed, we found that problem gambling severity is positively associated with self-reported financial stress. This overall finding is robust to alternative measures of financial stress and gambling behaviour. Gender-wise, we found that while males exhibited higher levels of problem gambling severity than females, females experienced higher levels of financial stress than males. Our findings showed that gambling widens the gender gap in financial stress over time. With respect to specific gambling activities, while scratch cards and poker machines are associated with higher levels of financial stress, horse and dog race betting is linked to lower levels of financial stress. In essence, the overall finding that gambling is associated with greater financial stress is largely driven by gambling activities, involving scratch cards and poker machines.

Our findings reveal that financial resilience serves as an important channel through which gambling influences financial stress. An important policy suggestion emerging from this finding is that designing policies around financial literacy and financial inclusion, which are known to enhance financial resilience, can help to provide the economic security needed to weaken the effect of gambling on financial stress. Apart from its potentially negative indirect effect on gambling through financial resilience, financial literacy is also known to have a direct negative relationship with problem gambling severity, due to its influence on informed financial behaviour. Financial inclusion can increase personal savings, which provide insulation in times of emergency. With respect to problem gambling severity, we encourage governments and gambling regulatory bodies to implement more policies that minimise the risk of people experiencing gambling-related harm, such as setting of cash and credit card limits, prevention of minors from engaging in gambling, removal of automated teller machines from gambling venues, and public campaigns to increase awareness about gambling-related harm. These policies can reduce gambling participation and reduce loss of savings and overindebtedness, which will indirectly contribute to efforts being made to reduce financial stress.

\section{Appendix}

See Tables 12, 13, 14, 15 and 16. 


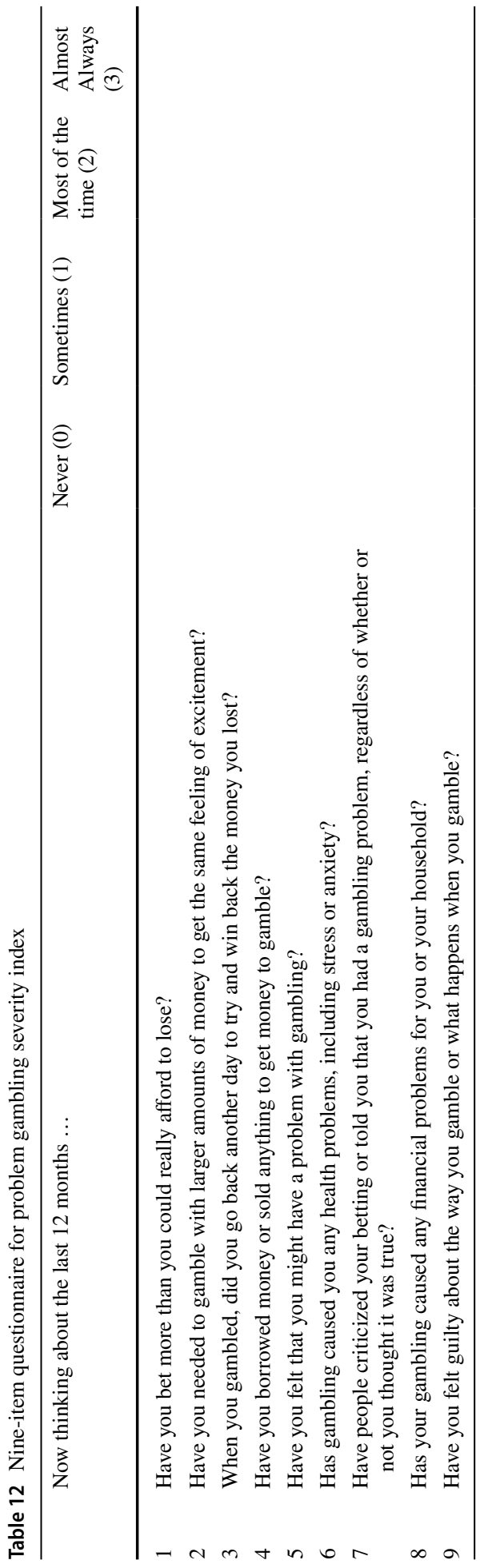




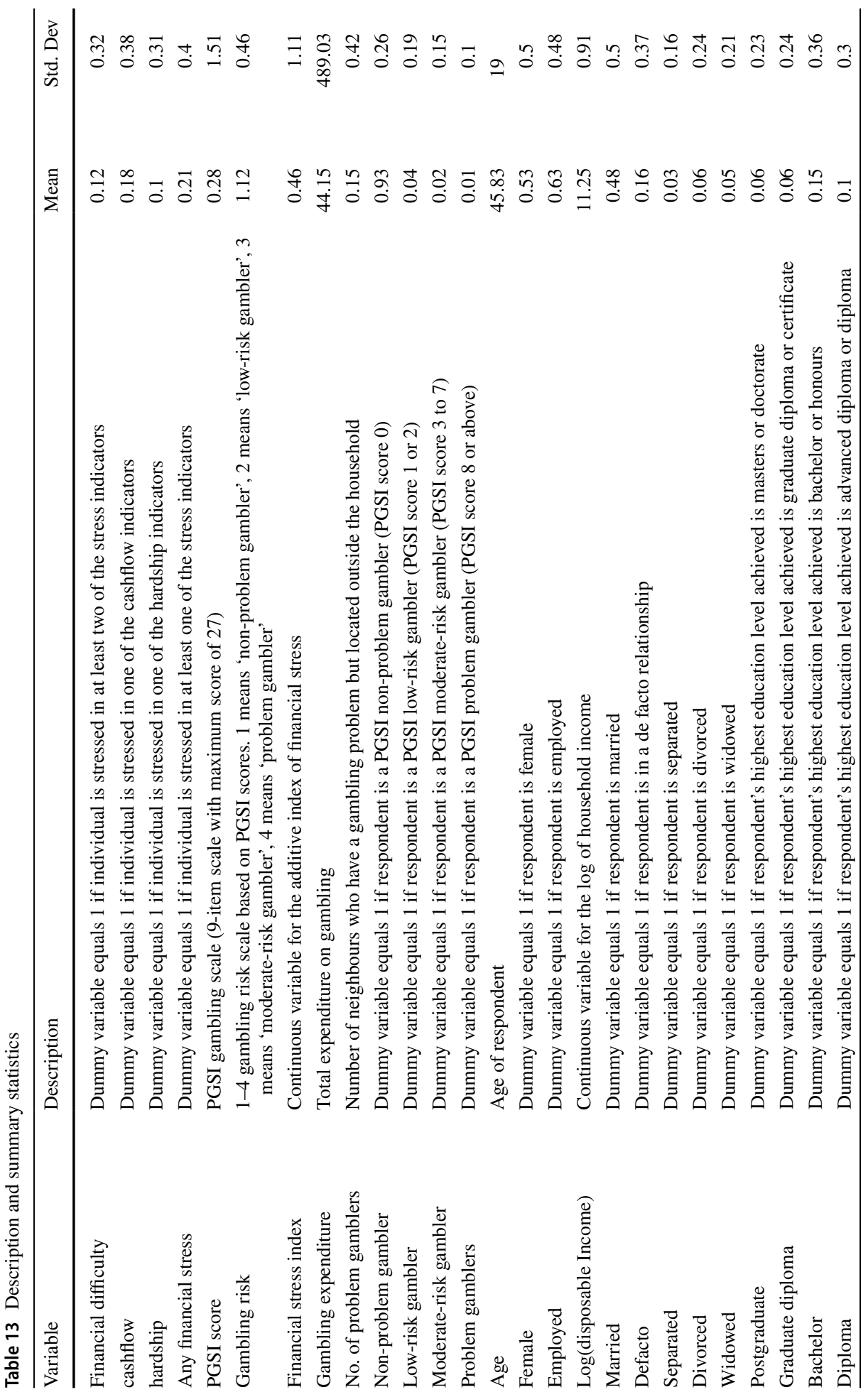




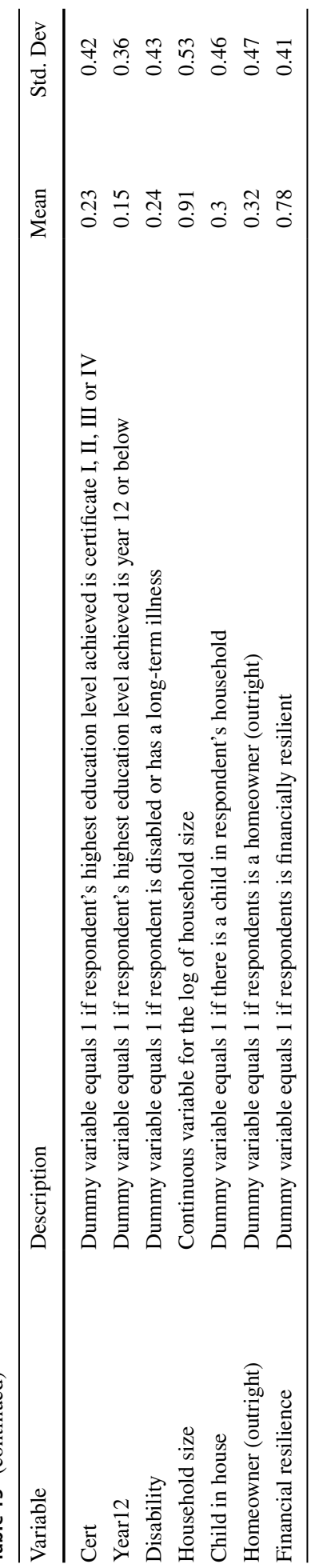


Table 14 Gambling and financial stress (Gender analysis)

\begin{tabular}{|c|c|c|c|c|}
\hline Variables & $\begin{array}{l}\text { Financial stress } \\
\text { (1) }\end{array}$ & $\begin{array}{l}\text { Cashflow } \\
\text { (2) }\end{array}$ & $\begin{array}{l}\text { Hardship } \\
\text { (3) }\end{array}$ & $\begin{array}{l}\text { Any stress } \\
\text { (4) }\end{array}$ \\
\hline \multicolumn{5}{|l|}{ Panel A(1): PGSI for male sample } \\
\hline PGSI & $\begin{array}{l}\mathbf{0 . 0 1 6} * * * \\
(0.002)\end{array}$ & $\begin{array}{l}\mathbf{0 . 0 2 0} * * * \\
(0.002)\end{array}$ & $\begin{array}{l}\mathbf{0 . 0 1 5} * * * \\
(0.002)\end{array}$ & $\begin{array}{l}\mathbf{0 . 0 2 0} * * * \\
(0.002)\end{array}$ \\
\hline All controls & Yes & Yes & Yes & Yes \\
\hline Observations & 14,406 & 14,406 & 14,406 & 14,406 \\
\hline R-squared & 0.085 & 0.095 & 0.091 & 0.108 \\
\hline \multicolumn{5}{|l|}{ Panel A(2): PGSI for female sample } \\
\hline PGSI & $\begin{array}{l}\mathbf{0 . 0 2 3} * * * \\
(0.003)\end{array}$ & $\begin{array}{l}\mathbf{0 . 0 2 4} * * * \\
(0.003)\end{array}$ & $\begin{array}{l}\mathbf{0 . 0 1 6}^{* * * *} \\
(0.003)\end{array}$ & $\begin{array}{l}\mathbf{0 . 0 2 5} * * * \\
(0.003)\end{array}$ \\
\hline All controls & Yes & Yes & Yes & Yes \\
\hline Observations & 16,322 & 16,322 & 16,322 & 16,322 \\
\hline R-squared & 0.108 & 0.111 & 0.106 & 0.127 \\
\hline Chow test: LR chi2: $\mathrm{A}(1)=\mathrm{A}(2)$ & $145.84 * * *$ & $109.32 * * *$ & $50.81 * * *$ & $85.20 * * *$ \\
\hline \multicolumn{5}{|c|}{ Panel B(1): Gambling risk for male sample } \\
\hline Gambling risk & $\begin{array}{l}\mathbf{0 . 0 4 9} * * * \\
(0.006)\end{array}$ & $\begin{array}{l}\mathbf{0 . 0 6 7} * * * \\
(0.007)\end{array}$ & $\begin{array}{l}\mathbf{0 . 0 4 3} * * * \\
(0.006)\end{array}$ & $\begin{array}{l}\mathbf{0 . 0 6 8}^{* * * *} \\
(0.007)\end{array}$ \\
\hline All controls & Yes & Yes & Yes & Yes \\
\hline Observations & 14,406 & 14,406 & 14,406 & 14,406 \\
\hline R-squared & 0.083 & 0.094 & 0.089 & 0.108 \\
\hline \multicolumn{5}{|c|}{ Panel B(2): Gambling risk for female sample } \\
\hline Gambling risk & $\begin{array}{l}\mathbf{0 . 0 7 3} * * * \\
(0.009)\end{array}$ & $\begin{array}{l}\mathbf{0 . 0 7 2} * * * \\
(0.009)\end{array}$ & $\begin{array}{l}\mathbf{0 . 0 5 7} * * * \\
(0.008)\end{array}$ & $\begin{array}{l}\mathbf{0 . 0 7 7} * * * \\
(0.009)\end{array}$ \\
\hline All controls & Yes & Yes & Yes & Yes \\
\hline Observations & 16,322 & 16,322 & 16,322 & 16,322 \\
\hline R-squared & 0.108 & 0.110 & 0.107 & 0.127 \\
\hline Chow test: $\mathrm{LR}$ chi2: $\mathrm{B}(1)=\mathrm{B}(2)$ & $142.28 * * *$ & $106.29 * * *$ & $51.19 * * *$ & $82.32 * * *$ \\
\hline
\end{tabular}

Robust standard errors in parentheses

*** $p<0.01, * * p<0.05, * p<0.1$ 
Table 15 PGSI and financial stress (Baseline results)

\begin{tabular}{|c|c|c|c|c|}
\hline Variables & $\begin{array}{l}\text { Financial stress } \\
\text { (1) }\end{array}$ & $\begin{array}{l}\text { Cashflow } \\
\text { (2) }\end{array}$ & $\begin{array}{l}\text { Hardship } \\
\text { (3) }\end{array}$ & $\begin{array}{l}\text { Any stress } \\
\text { (4) }\end{array}$ \\
\hline \multirow[t]{3}{*}{ PGSI } & $0.018 * * *$ & $0.021 * * *$ & $0.015^{* * *}$ & $0.021 * * *$ \\
\hline & $(0.002)$ & $(0.002)$ & $(0.002)$ & $(0.002)$ \\
\hline & {$[0.086]$} & {$[0.084]$} & {$[0.075]$} & {$[0.080]$} \\
\hline \multirow[t]{3}{*}{$\log$ (Age) } & $-0.034 * * *$ & $-0.060 * * *$ & $-0.039 * * *$ & $-0.063^{* * *}$ \\
\hline & $(0.007)$ & $(0.008)$ & $(0.007)$ & $(0.008)$ \\
\hline & {$[-0.048]$} & {$[-0.072]$} & {$[-0.059]$} & {$[-0.071]$} \\
\hline \multirow[t]{3}{*}{ Female } & $0.024 * * *$ & $0.034 * * *$ & $0.007 *$ & $0.030^{* * *}$ \\
\hline & $(0.004)$ & $(0.004)$ & $(0.003)$ & $(0.004)$ \\
\hline & {$[0.038]$} & {$[0.044]$} & {$[0.011]$} & {$[0.037]$} \\
\hline \multirow[t]{3}{*}{ Employed } & $-0.047 * * *$ & $-0.027 * * *$ & $-0.068 * * *$ & $-0.044 * * *$ \\
\hline & $(0.005)$ & $(0.005)$ & $(0.005)$ & $(0.006)$ \\
\hline & {$[-0.070]$} & {$[-0.034]$} & {$[-0.108]$} & {$[-0.052]$} \\
\hline \multirow[t]{3}{*}{ Log (disposable income) } & $-0.036^{* * *}$ & $-0.047 * * *$ & $-0.039 * * *$ & $-0.057 * * *$ \\
\hline & $(0.003)$ & $(0.004)$ & $(0.003)$ & $(0.004)$ \\
\hline & {$[-0.103]$} & {$[-0.112]$} & {$[-0.116]$} & {$[-0.128]$} \\
\hline \multirow[t]{3}{*}{ Married } & $-0.042 * * *$ & $-0.038 * * *$ & $-0.046^{* * *}$ & $-0.048^{* * *}$ \\
\hline & $(0.007)$ & $(0.008)$ & $(0.007)$ & $(0.008)$ \\
\hline & {$[-0.065]$} & {$[-0.050]$} & {$[-0.075]$} & {$[-0.060]$} \\
\hline \multirow[t]{3}{*}{ Defacto } & $0.028 * * *$ & $0.049 * * *$ & $0.016^{* *}$ & $0.047 * * *$ \\
\hline & $(0.007)$ & $(0.008)$ & $(0.007)$ & $(0.009)$ \\
\hline & {$[0.032]$} & {$[0.047]$} & {$[0.019]$} & {$[0.043]$} \\
\hline \multirow[t]{3}{*}{ Separated } & $0.083^{* * *}$ & $0.090 * * *$ & $0.080 * * *$ & $0.108 * * *$ \\
\hline & $(0.016)$ & $(0.017)$ & $(0.016)$ & $(0.018)$ \\
\hline & {$[0.040]$} & {$[0.037]$} & {$[0.041]$} & {$[0.042]$} \\
\hline \multirow[t]{3}{*}{ Divorced } & $0.047 * * *$ & $0.050 * * *$ & $0.048 * * *$ & $0.065 * * *$ \\
\hline & $(0.011)$ & $(0.012)$ & $(0.011)$ & $(0.013)$ \\
\hline & {$[0.035]$} & {$[0.031]$} & {$[0.037]$} & {$[0.039]$} \\
\hline \multirow[t]{3}{*}{ Widowed } & $-0.069 * * *$ & $-0.039 * * *$ & $-0.061 * * *$ & $-0.050^{* * *}$ \\
\hline & $(0.011)$ & $(0.013)$ & $(0.011)$ & $(0.013)$ \\
\hline & {$[-0.045]$} & {$[-0.021]$} & {$[-0.042]$} & {$[-0.026]$} \\
\hline \multirow[t]{3}{*}{ Postgraduate } & $-0.035^{* * *}$ & $-0.038^{* * *}$ & $-0.022 * * *$ & $-0.044^{* * *}$ \\
\hline & $(0.007)$ & $(0.009)$ & $(0.006)$ & $(0.009)$ \\
\hline & {$[-0.025]$} & {$[-0.023]$} & {$[-0.017]$} & {$[-0.026]$} \\
\hline \multirow[t]{3}{*}{ Graduate Diploma } & $-0.021 * * *$ & $-0.031 * * *$ & -0.010 & $-0.028^{* * *}$ \\
\hline & $(0.007)$ & $(0.009)$ & $(0.006)$ & $(0.009)$ \\
\hline & {$[-0.015]$} & {$[-0.019]$} & {$[-0.008]$} & {$[-0.017]$} \\
\hline \multirow[t]{3}{*}{ Bachelor } & $-0.035^{* * *}$ & $-0.031 * * *$ & $-0.019 * * *$ & $-0.028^{* * *}$ \\
\hline & $(0.006)$ & $(0.007)$ & $(0.005)$ & $(0.007)$ \\
\hline & {$[-0.039]$} & {$[-0.029]$} & {$[-0.022]$} & {$[-0.025]$} \\
\hline \multirow[t]{3}{*}{ Diploma } & 0.005 & 0.010 & 0.005 & 0.012 \\
\hline & $(0.007)$ & (0.008) & $(0.006)$ & $(0.008)$ \\
\hline & {$[0.005]$} & {$[0.008]$} & {$[0.005]$} & {$[0.009]$} \\
\hline
\end{tabular}


Table 15 (continued)

\begin{tabular}{|c|c|c|c|c|}
\hline Variables & $\begin{array}{l}\text { Financial stress } \\
\text { (1) }\end{array}$ & $\begin{array}{l}\text { Cashflow } \\
\text { (2) }\end{array}$ & $\begin{array}{l}\text { Hardship } \\
\text { (3) }\end{array}$ & $\begin{array}{l}\text { Any stress } \\
\text { (4) }\end{array}$ \\
\hline \multirow[t]{3}{*}{ Certificate } & $0.033 * * *$ & $0.046^{* * *}$ & $0.032 * * *$ & $0.053 * * *$ \\
\hline & $(0.006)$ & $(0.007)$ & $(0.006)$ & $(0.007)$ \\
\hline & {$[0.044]$} & {$[0.050]$} & [0.044] & {$[0.055]$} \\
\hline \multirow[t]{3}{*}{ Year 12} & 0.001 & $0.016^{* *}$ & 0.004 & $0.021 * * *$ \\
\hline & $(0.006)$ & $(0.007)$ & $(0.006)$ & $(0.008)$ \\
\hline & {$[0.001]$} & {$[0.015]$} & {$[0.004]$} & {$[0.018]$} \\
\hline \multirow[t]{3}{*}{ Disability } & $0.066 * * *$ & $0.073 * * *$ & $0.067 * * *$ & $0.090 * * *$ \\
\hline & $(0.005)$ & $(0.006)$ & $(0.005)$ & $(0.006)$ \\
\hline & {$[0.088]$} & {$[0.081]$} & {$[0.094]$} & {$[0.095]$} \\
\hline \multirow[t]{3}{*}{ Log (household size) } & 0.007 & $0.015^{* *}$ & 0.004 & $0.013 *$ \\
\hline & $(0.006)$ & $(0.007)$ & $(0.006)$ & $(0.007)$ \\
\hline & {$[0.012]$} & {$[0.021]$} & {$[0.007]$} & {$[0.017]$} \\
\hline \multirow[t]{3}{*}{ Child in house } & $0.059 * * *$ & $0.076^{* * *}$ & $0.040 * * *$ & $0.077 * * *$ \\
\hline & $(0.005)$ & $(0.007)$ & $(0.005)$ & $(0.007)$ \\
\hline & {$[0.084]$} & {$[0.091]$} & {$[0.060]$} & {$[0.087]$} \\
\hline \multirow[t]{3}{*}{ Homeowner (outright) } & $-0.093 * * *$ & $-0.122 * * *$ & $-0.081 * * *$ & $-0.139 * * *$ \\
\hline & $(0.004)$ & $(0.005)$ & $(0.004)$ & $(0.005)$ \\
\hline & {$[-0.135]$} & {$[-0.148]$} & {$[-0.124]$} & {$[-0.160]$} \\
\hline Wave fixed effect & Yes & Yes & Yes & Yes \\
\hline State fixed effect & Yes & Yes & Yes & Yes \\
\hline Observations & 30,728 & 30,728 & 30,728 & 30,728 \\
\hline R-squared & 0.097 & 0.103 & 0.098 & 0.118 \\
\hline
\end{tabular}

Robust standard errors in parentheses ***p $<0.01, * * \mathrm{p}<0.05, * \mathrm{p}<0.1$

Standardised coefficients in square brackets 
Table 16 Gambling risk status and financial stress (Baseline results)

\begin{tabular}{|c|c|c|c|c|}
\hline Variables & $\begin{array}{l}\text { Financial stress } \\
\text { (5) }\end{array}$ & $\begin{array}{l}\text { Cashflow } \\
\text { (6) }\end{array}$ & $\begin{array}{l}\text { Hardship } \\
\text { (7) }\end{array}$ & $\begin{array}{l}\text { Any stress } \\
\text { (8) }\end{array}$ \\
\hline \multirow[t]{3}{*}{ Gambling risk status } & $0.057 * * *$ & $0.069 * * *$ & $0.048 * * *$ & $0.071^{* * *}$ \\
\hline & $(0.005)$ & $(0.006)$ & $(0.005)$ & $(0.006)$ \\
\hline & {$[0.082]$} & {$[0.083]$} & {$[0.073]$} & {$[0.081]$} \\
\hline \multirow[t]{3}{*}{$\log$ (Age) } & $-0.035^{* * *}$ & $-0.062 * * *$ & $-0.040 * * *$ & $-0.065^{* * *}$ \\
\hline & $(0.007)$ & $(0.008)$ & $(0.007)$ & $(0.008)$ \\
\hline & {$[-0.050]$} & {$[-0.074]$} & {$[-0.060]$} & {$[-0.073]$} \\
\hline \multirow[t]{3}{*}{ Female } & $0.025^{* * *}$ & $0.035^{* * *}$ & $0.007 * *$ & $0.031 * * *$ \\
\hline & $(0.004)$ & $(0.004)$ & $(0.003)$ & $(0.004)$ \\
\hline & {$[0.039]$} & {$[0.045]$} & {$[0.012]$} & {$[0.039]$} \\
\hline \multirow[t]{3}{*}{ Employed } & $-0.047 * * *$ & $-0.027 * * *$ & $-0.068 * * *$ & $-0.044 * * *$ \\
\hline & $(0.005)$ & $(0.005)$ & $(0.005)$ & $(0.006)$ \\
\hline & {$[-0.070]$} & {$[-0.034]$} & {$[-0.108]$} & {$[-0.052]$} \\
\hline \multirow[t]{3}{*}{ Log (disposable income) } & $-0.036^{* * *}$ & $-0.047 * * *$ & $-0.039 * * *$ & $-0.056^{* * *}$ \\
\hline & $(0.003)$ & $(0.004)$ & $(0.003)$ & $(0.004)$ \\
\hline & {$[-0.102]$} & {$[-0.111]$} & {$[-0.116]$} & {$[-0.128]$} \\
\hline \multirow[t]{3}{*}{ Married } & $-0.041^{* * *}$ & $-0.037 * * *$ & $-0.045^{* * *}$ & $-0.047 * * *$ \\
\hline & $(0.007)$ & $(0.008)$ & $(0.007)$ & $(0.008)$ \\
\hline & {$[-0.064]$} & {$[-0.049]$} & {$[-0.074]$} & {$[-0.058]$} \\
\hline \multirow[t]{3}{*}{ Defacto } & $0.028 * * *$ & $0.049 * * *$ & $0.016^{* *}$ & $0.048 * * *$ \\
\hline & $(0.007)$ & $(0.008)$ & $(0.007)$ & $(0.009)$ \\
\hline & {$[0.032]$} & {$[0.047]$} & {$[0.019]$} & {$[0.043]$} \\
\hline \multirow[t]{3}{*}{ Separated } & $0.083^{* * * *}$ & $0.090 * * *$ & $0.079 * * *$ & $0.108 * * *$ \\
\hline & $(0.016)$ & $(0.017)$ & $(0.016)$ & $(0.018)$ \\
\hline & {$[0.040]$} & {$[0.037]$} & [0.041] & {$[0.042]$} \\
\hline \multirow[t]{3}{*}{ Divorced } & $0.048^{* * * *}$ & $0.051 * * *$ & $0.048 * * *$ & $0.066 * * *$ \\
\hline & $(0.011)$ & $(0.012)$ & $(0.011)$ & $(0.013)$ \\
\hline & {$[0.036]$} & {$[0.032]$} & {$[0.038]$} & {$[0.040]$} \\
\hline \multirow[t]{3}{*}{ Widowed } & $-0.069 * * *$ & $-0.039 * * *$ & $-0.061 * * *$ & $-0.049^{* * *}$ \\
\hline & $(0.011)$ & $(0.013)$ & $(0.011)$ & $(0.013)$ \\
\hline & {$[-0.044]$} & {$[-0.021]$} & {$[-0.042]$} & {$[-0.025]$} \\
\hline \multirow[t]{3}{*}{ Postgraduate } & $-0.034 * * *$ & $-0.037 * * *$ & $-0.021 * * *$ & $-0.043^{* * *}$ \\
\hline & $(0.007)$ & $(0.009)$ & $(0.006)$ & $(0.009)$ \\
\hline & {$[-0.025]$} & {$[-0.022]$} & {$[-0.016]$} & {$[-0.025]$} \\
\hline \multirow[t]{3}{*}{ Graduate diploma } & $-0.021 * * *$ & $-0.030 * * *$ & -0.010 & $-0.028^{* * *}$ \\
\hline & $(0.007)$ & $(0.009)$ & $(0.006)$ & $(0.009)$ \\
\hline & {$[-0.015]$} & {$[-0.019]$} & {$[-0.008]$} & {$[-0.016]$} \\
\hline \multirow[t]{3}{*}{ Bachelor } & $-0.035^{* * *}$ & $-0.031 * * *$ & $-0.019 * * *$ & $-0.028^{* * *}$ \\
\hline & $(0.006)$ & $(0.007)$ & $(0.005)$ & $(0.007)$ \\
\hline & {$[-0.039]$} & {$[-0.029]$} & {$[-0.022]$} & {$[-0.025]$} \\
\hline \multirow[t]{3}{*}{ Diploma } & 0.005 & 0.010 & 0.005 & 0.012 \\
\hline & $(0.007)$ & (0.008) & $(0.006)$ & $(0.008)$ \\
\hline & {$[0.004]$} & {$[0.008]$} & {$[0.005]$} & {$[0.009]$} \\
\hline
\end{tabular}


Table 16 (continued)

\begin{tabular}{lllll}
\hline Variables & $\begin{array}{l}\text { Financial stress } \\
(5)\end{array}$ & $\begin{array}{l}\text { Cashflow } \\
(6)\end{array}$ & $\begin{array}{l}\text { Hardship } \\
(7)\end{array}$ & $\begin{array}{l}\text { Any stress } \\
(8)\end{array}$ \\
\hline Certificate & $0.033^{* * *}$ & $0.045^{* * *}$ & $0.031^{* * *}$ & $0.052^{* * * *}$ \\
& $(0.006)$ & $(0.007)$ & $(0.006)$ & $(0.007)$ \\
& {$[0.043]$} & {$[0.049]$} & {$[0.043]$} & {$[0.054]$} \\
Year 12 & 0.001 & $0.015^{* *}$ & 0.004 & $0.021^{* * *}$ \\
& $(0.006)$ & $(0.007)$ & $(0.006)$ & $(0.008)$ \\
Disability & {$[0.001]$} & {$[0.014]$} & {$[0.004]$} & {$[0.018]$} \\
& $0.066^{* * *}$ & $0.073^{* * *}$ & $0.067^{* * *}$ & $0.090^{* * *}$ \\
Log (household size) & $(0.005)$ & $(0.006)$ & $(0.005)$ & $(0.006)$ \\
& {$[0.088]$} & {$[0.081]$} & {$[0.094]$} & {$[0.095]$} \\
Child in house & 0.007 & $0.015^{* *}$ & 0.004 & $0.013 *$ \\
& $(0.006)$ & $(0.007)$ & $(0.006)$ & $(0.007)$ \\
& {$[0.012]$} & {$[0.021]$} & {$[0.006]$} & {$[0.017]$} \\
Homeowner (outright) & $0.059^{* * *}$ & $0.077^{* * *}$ & $0.040^{* * *}$ & $0.078^{* * *}$ \\
& $(0.005)$ & $(0.007)$ & $(0.005)$ & $(0.007)$ \\
& {$[0.084]$} & {$[0.092]$} & {$[0.060]$} & {$[0.088]$} \\
Wave fixed effect & $-0.093^{* * *}$ & $-0.121^{* * *}$ & $-0.081^{* * *}$ & $-0.139^{* * *}$ \\
State fixed effect & $(0.004)$ & $(0.005)$ & $(0.004)$ & $(0.005)$ \\
Observations & {$[-0.135]$} & {$[-0.148]$} & {$[-0.124]$} & {$[-0.160]$} \\
R-squared & Yes & Yes & Yes & Yes \\
\hline & Yes & Yes & Yes & Yes \\
Res & 30,728 & 30,728 & 30,728 & 30,728 \\
& 0.096 & 0.103 & 0.098 & 0.118 \\
\hline
\end{tabular}

Robust standard errors in parentheses $* * * p<0.01,{ }^{* *} p<0.05,{ }^{*} p<0.1$

Standardised coefficients in square brackets

Acknowledgements This article uses unit record data from the Household, Income and Labour Dynamics in Australia (HILDA) Survey. The HILDA Project was initiated and is funded by the Australian Government Department of Social Services (DSS) and is managed by the Melbourne Institute of Applied Economic and Social Research (Melbourne Institute). The findings and views reported in this article, however, are those of the authors and should not be attributed to either DSS or the Melbourne Institute.

Funding Open Access funding enabled and organized by CAUL and its Member Institutions.

Open Access This article is licensed under a Creative Commons Attribution 4.0 International License, which permits use, sharing, adaptation, distribution and reproduction in any medium or format, as long as you give appropriate credit to the original author(s) and the source, provide a link to the Creative Commons licence, and indicate if changes were made. The images or other third party material in this article are included in the article's Creative Commons licence, unless indicated otherwise in a credit line to the material. If material is not included in the article's Creative Commons licence and your intended use is not permitted by statutory regulation or exceeds the permitted use, you will need to obtain permission directly from the copyright holder. To view a copy of this licence, visit http://creativecommons.org/licenses/by/4.0/. 


\section{References}

Alesina, A., \& Zhuravskaya, E. (2011). Segregation and the quality of government in a cross section of countries. The American Economic Review, 101(5), 1872-1911. https://doi.org/10.2307/23045625

Allami, Y., Hodgins, D. C., Young, M., Brunelle, N., Currie, S., Dufour, M., ... \& Nadeau, L. (2021). A meta-analysis of problem gambling risk factors in the general adult population. Addiction. doi:https:// doi.org/10.1111/add.15449

Armstrong, A., \& Carroll, M. (2017). Gambling activity in Australia: Findings from wave 15 of the household, income and labour dynamics in Australia (HILDA) survey. Australian Gambling Research Centre. Retrieved from https://aifs.gov.au/agrc/sites/default/files/publication-documents/rr-gambling_activ ity_in_australia_0.pdf

Awaworyi Churchill, S., \& Farrell, L. (2020b). Gambling and Subjective Wellbeing of Older Australians. In S. Awaworyi Churchill, L. Farrell, \& S. Appau (Eds.), Measuring, understanding and improving wellbeing among older people (pp. 97-116). Springer.

Awaworyi Churchill, S., \& Farrell, L. (2018). The impact of gambling on depression: New evidence from England and Scotland. Economic Modelling, 68, 475-483. https://doi.org/10.1016/j.econmod.2017.08. 021

Awaworyi Churchill, S., \& Farrell, L. (2019). Social capital and gambling: Evidence from Australia. Journal of Gambling Studies. https://doi.org/10.1007/s10899-019-09901-9

Awaworyi Churchill, S., \& Farrell, L. (2020a). Australia's gambling epidemic: The role of neighbourhood ethnic diversity. Journal of Gambling Studies, 36(1), 97-118. https://doi.org/10.1007/ s10899-019-09865-w

Awaworyi Churchill, S., Farrell, L., \& Smyth, R. (2019). Neighbourhood ethnic diversity and mental health in Australia. Health Economics, 28(9), 1075-1087. https://doi.org/10.1002/hec.3928

Blaszczynski, A., \& Nower, L. (2002). A pathways model of problem and pathological gambling. Addiction, 97(5), 487-499. https://doi.org/10.1046/j.1360-0443.2002.00015.x.

Broadway, B, Payne A. A. \& Salamanca, N. (Eds.) (2020). Coping with COVID-19: Rethinking Australia. Melbourne Institute: Applied Economic \& Social Research, the University of Melbourne. https:// melbourneinstitute.unimelb.edu.au/publications/research-insights

Belayeth Hussain, A. H. M., Endut, N., Das, S., Chowdhury, M. T. A., Haque, N., Sultana, S., \& Ahmed, K. J. (2019). Does financial inclusion increase financial resilience? Evidence from Bangladesh. Development in Practice, 29(6), 798-807.

Blanco, C., Myers, J., \& Kendler, K. (2012). Gambling, disordered gambling and their association with major depression and substance use: A web-based cohort and twin-sibling study. Psychological Medicine, 42(3), 497.

Bray, J. R. (2001). Hardship in Australia: An analysis of financial stress indicators in the 1998-99 Australian bureau of statistics household expenditure survey. Department of Family and Community Services.

Breunig, R., \& Cobb-Clark, D. (2006). Understanding the factors associated with financial stress in Australian households. Australian Social Policy, 2005, 13-64.

Breunig, R., Hasan, S., \& Hunter, B. (2019). Financial stress and indigenous Australians. Economic Record, 95(308), 34-57.

Browne, M., Greer, N., Armstrong, T., Doran, C., Kinchin, I., Langham, E., \& Rockloff, M. (2017). The social cost of gambling to Victoria. Victorian Responsible Gambling Foundation.

Buchanan, T. W., McMullin, S. D., Baxley, C., \& Weinstock, J. (2020). Stress and gambling. Current Opinion in Behavioral Sciences, 31, 8-12.

Calado, F., \& Griffiths, M. D. (2016). Problem gambling worldwide: An update and systematic review of empirical research (2000-2015). Journal of Behavioral Addictions, 5(4), 592-613.

Central Coast Gambling Help. (2017). Problem gambling and financial stress. Retrieved from http:// www.problemgambling.net.au/financialstress.html

Chow, G. C. (1960). Tests of equality between sets of coefficients in two linear regressions. Econometrica, 28(3), 591-605.

Currie, S. R., Hodgins, D. C., \& Casey, D. M. (2013). Validity of the problem gambling severity index interpretive categories. Journal of Gambling Studies, 29(2), 311-327. https://doi.org/10.1007/ s10899-012-9300-6

Dahl, E., Tagler, M. J., \& Hohman, Z. P. (2018). Gambling and the reasoned action model: Predicting past behavior, intentions, and future behavior. Journal of Gambling Studies, 34(1), 101-118. https://doi. org/10.1007/s10899-017-9702-6 
Darbyshire, P., Oster, C., \& Carrig, H. (2001). The experience of pervasive loss: Children and young people living in a family where parental gambling is a problem. Journal of Gambling Studies, 17(1), $23-45$. https://doi.org/10.1023/A:1014536315167

Demirgüç-Kunt, A., Klapper, L., Singer, D., Ansar, S., \& Hess, J. (2020). The global findex database 2017: Measuring financial inclusion and opportunities to expand access to and use of financial services. The World Bank Economic Review, 34(Supplement_1), S2-S8.

Dickson-Swift, V. A., James, E. L., \& Kippen, S. (2005). The experience of living with a problem gambler: Spouses and partners speak out. Journal of Gambling Issues (13), 1-22.

Dobson, R. (2004). Poor more likely to smoke and less likely to quit. British Medical Journal, 328(7445), 914.

Dowling, N. A., Ewin, C., Youssef, G. J., Merkouris, S. S., Suomi, A., Thomas, S. A., \& Jackson, A. C. (2018). Problem gambling and family violence: Findings from a population-representative study. Journal of Behavioral Addictions, 7(3), 806-813. https://doi.org/10.1556/2006.7.2018.74

Dowling, N., Smith, D., \& Thomas, T. (2005). Electronic gaming machines: Are they the 'crack-cocaine'of gambling? Addiction, 100(1), 33-45.

Ferris, J. A., \& Wynne, H. J. (2001). The Canadian problem gambling index. Canadian Centre on Substance Abuse.

Furaker, B., \& Hedenus, A. (2009). Gambling windfall decisions: Lottery winners and employment behavior. UNLV Gaming Research \& Review Journal, 13(2). Retrieved from https://digitalscholarship.unlv. edu/grrj/vol13/iss $2 / 1$

Gong, X., \& Zhu, R. (2019). Cognitive abilities, non-cognitive skills, and gambling behaviors. Journal of Economic Behavior \& Organization, 165, 51-69.

Graham, H. (1993). When life's a drag: Women, smoking and disadvantage. Department of Health.

Griswold, M. T., \& Nichols, M. W. (2006). Social capital and casino gambling in US communities. Social Indicators Research, 77(3), 369-394.

Holtgraves, T. (2008). Evaluating the problem gambling severity index. Journal of Gambling Studies, 25(1), 105. https://doi.org/10.1007/s10899-008-9107-7

Jackson, A. C., Wynne, H., Dowling, N. A., Tomnay, J. E., \& Thomas, S. A. (2010). Using the CPGI to determine problem gambling prevalence in Australia: Measurement issues. International Journal of Mental Health and Addiction, 8(4), 570-582. https://doi.org/10.1007/s11469-009-9238-9

Kalischuk, R. G. (2010). Cocreating life pathways: Problem gambling and its impact on families. The Family Journal, 18(1), 7-17. https://doi.org/10.1177/1066480709357898

Kalischuk, R. G., Nowatzki, N., Cardwell, K., Klein, K., \& Solowoniuk, J. (2006). Problem gambling and its impact on families: A literature review. International Gambling Studies, 6(1), 31-60.

Klapper, L., \& Lusardi, A. (2020). Financial literacy and financial resilience: Evidence from around the world. Financial Management, 49(3), 589-614.

Koomson, I., \& Awaworyi Churchill, S. (2021). Ethnic diversity and food insecurity: Evidence from Ghana. The Journal of Development Studies. https://doi.org/10.1080/00220388.2021.1928641

Koomson, I., Bukari, C., \& Villano, R. A. (2021). Mobile money adoption and response to idiosyncratic shocks: Empirics from five selected countries in sub-Saharan Africa. Technological Forecasting and Social Change, 167, 120728. https://doi.org/10.1016/j.techfore.2021.120728

Koomson, I., \& Danquah, M. (2021). Financial inclusion and energy poverty: Empirical evidence from Ghana. Energy Economics. https://doi.org/10.1016/j.eneco.2020.105085

Koomson, I., Villano, R. A., \& Hadley, D. (2020a). Intensifying financial inclusion through the provision of financial literacy training: A gendered perspective. Applied Economics, 52(4), 375-387.

Koomson, I., Villano, R. A., \& Hadley, D. (2020b). Effect of financial inclusion on poverty and vulnerability to poverty: Evidence using a multidimensional measure of financial inclusion. Social Indicators Research, 149(2), 613-639.

Korman, L. M., Collins, J., Dutton, D., Dhayananthan, B., Littman-Sharp, N., \& Skinner, W. (2008). Problem gambling and intimate partner violence. Journal of Gambling Studies, 24(1), 13-23. https://doi. org/10.1007/s10899-007-9077-1

Kourgiantakis, T., Saint-Jacques, M.-C., \& Tremblay, J. (2013). Problem gambling and families: A systematic review. Journal of Social Work Practice in the Addictions, 13(4), 353-372.

Larsson, B. (2011). Becoming a winner but staying the same: Identities and consumption of Lottery winners. American Journal of Economics and Sociology, 70(1), 187-209. https://doi.org/10.1111/j. 1536-7150.2010.00768.x

Le, T. (2016). The effects of gambling on the financial well-being and perceived social support of family members: A quantitative study. California State University. 
Loo, J. M. Y., Oei, T. P. S., \& Raylu, N. (2011). Psychometric evaluation of the problem gambling severity index-chinese version (PGSI-C). Journal of Gambling Studies, 27(3), 453-466. https://doi.org/ 10.1007/s10899-010-9221-1

Lusardi, A., Hasler, A., \& Yakoboski, P. J. (2020). Building up financial literacy and financial resilience. Mind \& Society, 1-7.

Mathews, M., \& Volberg, R. (2013). Impact of problem gambling on financial, emotional and social well-being of Singaporean families. International Gambling Studies, 13(1), 127-140.

McComb, J. L., Lee, B. K., \& Sprenkle, D. H. (2009). Conceptualizing and treating problem gambling as a family issue. Journal of Marital and Family Therapy, 35(4), 415-431.

Muggleton, N., Parpart, P., Newall, P., Leake, D., Gathergood, J., \& Stewart, N. (2021). The association between gambling and financial, social and health outcomes in big financial data. Nature Human Behaviour. https://doi.org/10.1038/s41562-020-01045-w

NAB. (2020). NAB Australian Wellbeing Report: Q4 2019. National Australia Bank (NAB) Behavioural \& IndustryEconomics.

Oksanen, A., Savolainen, I., Sirola, A., \& Kaakinen, M. (2018). Problem gambling and psychological distress: Across-national perspective on the mediating effect of consumer debt and debt problems among emerging adults. Harm Reduction Journal, 15(1), 1-11. https://doi.org/10.1186/s12954-018-0251-9.

Paterson, M., Taylor, M., \& Gray, M. (2020). Trajectories of social and economic outcomes and problem gambling risk in Australia. Social Indicators Research, 148(1), 297-321.

Patford, J. L. (2007). Linked lives: Adult children's experiences of late onset parental gambling problems. International Journal of Mental Health and Addiction, 5(4), 367-380.

Quigley, L., Yakovenko, I., Hodgins, D. C., Dobson, K. S., El-Guebaly, N., Casey, D. M., ... Schopflocher, D. P. (2015). Comorbid Problem Gambling and Major Depression in a Community Sample. Journal of Gambling Studies, 31(4), 1135-1152.

Raisamo, S. U., Mäkelä, P., Salonen, A. H., \& Lintonen, T. P. (2014). The extent and distribution of gambling harm in Finland as assessed by the problem gambling severity index. The European Journal of Public Health, 25(4), 716-722.

Russell, A., Langham, E., Hing, N., \& Rawat, V. (2018). Social influences on gamblers by risk group: An egocentric social network analysis. Victorian Responsible Gambling Foundation.

Saugeres, L., Thomas, A., Moore, S., \& Bates, G. (2012). Gamblers tell their stories: Life patterns of gambling. Victorian Responsible Gambling Foundation.

Siahpush, M., Borland, R., \& Scollo, M. (2003). Smoking and financial stress. Tobacco Control, 12(1), 60-66.

Siahpush, M., \& Carlin, J. B. (2006). Financial stress, smoking cessation and relapse: Results from a prospective study of an Australian national sample. Addiction, 101(1), 121-127.

Siahpush, M., Spittal, M., \& Singh, G. K. (2007). Smoking cessation and financial stress. Journal of Public Health, 29(4), 338-342.

Stock, J. H., \& Yogo, M. (2005). Testing for weak instruments in linear IV regression. In D. Andrews \& J. Stock (Eds.), Identification and inference for econometric models: Essays in honor of thomas rothenberg (pp. 80-105). Cambridge University Press.

Stöckl, T., Huber, J., Kirchler, M., \& Lindner, F. (2015). Hot hand and gambler's fallacy in teams: Evidence from investment experiments. Journal of Economic Behavior \& Organization, 117, 327-339.

Suomi, A., Jackson, A., Dowling, N., Lavis, T., Patford, J., Thomas, S., . . Cockman, S. (2013). Problem gambling and family violence: Family member reports of prevalence, family impacts and family coping. Asian Journal of Gambling Issues and Public Health, 3(1), 13. https://doi.org/10.1186/ 2195-3007-3-13

Swanton, T. B., \& Gainsbury, S. M. (2020). Gambling-related consumer credit use and debt problems: A brief review. Current Opinion in Behavioral Sciences, 31, 21-31. https://doi.org/10.1016/j.cobeha. 2019.09.002

Tabri, N., Xuereb, S., Cringle, N., \& Clark, L. (2022). Associations between financial gambling motives, gambling frequency and level of problem gambling: a meta-analytic review. Addiction, 117(3), 559569. https://doi.org/10.1111/add.15642.

Queensland Treasury. (2021). Australian gambling statistics (36th ed.). Brisbane: Queensland Government Statistician's Office, Queensland Treasury. Retrived from https://www.qgso.qld.gov.au/stati stics/theme/society/gambling/australian-gambling-statistics.

Watanapongvanich, S., Binnagan, P., Putthinun, P., Khan, M. S. R., \& Kadoya, Y. (2020). Financial literacy and gambling behavior: Evidence from Japan. Journal of Gambling Studies. https://doi.org/ $10.1007 / \mathrm{s} 10899-020-09936-3$

Watson, N., \& Wooden, M. P. (2012). The HILDA survey: A case study in the design and development of a successful household panel survey. Longitudinal and Life Course Studies, 3(3), 369-381. 
Widdowson, D., \& Hailwood, K. (2007). Financial literacy and its role in promoting a sound financial system. Reserve Bank of New Zealand Bulletin, 70(2), 37-47. https://www.rbnz.govt.nz/-/media/reser vebank/files/publications/bulletins/2007/2007jun70-2widdowsonhailwood.pdf

Widome, R., Joseph, A. M., Hammett, P., Van Ryn, M., Nelson, D. B., Nyman, J. A., \& Fu, S. S. (2015). Associations between smoking behaviors and financial stress among low-income smokers. Preventive Medicine Reports, 2, 911-915. https://doi.org/10.1016/j.pmedr.2015.10.011

Wilkins, R., \& Lass, I. (2015). The household, income and labour dynamics in Australia survey: Selected findings from waves 1 to 12. Melbourne Institute of Applied Economic and Social Research.

World Bank. (2018). Financial Inclusion. World Bank. http://www.worldbank.org/en/topic/financialinclus ion/overview

Xu, J., \& Harvey, N. (2014). Carry on winning: The gamblers' fallacy creates hot hand effects in online gambling. Cognition, 131(2), 173-180.

Publisher's Note Springer Nature remains neutral with regard to jurisdictional claims in published maps and institutional affiliations. 